\title{
How Do We Explain the Quiet Demise of Graeco-Roman Religion? An Essay
}

\author{
Jan N. Bremmer \\ Faculty of Theology and Religious Studies, University of Groningen, \\ Groningen, The Netherlands \\ j.n.bremmer@rug.nl
}

\begin{abstract}
Until now, the relatively quiet transition from traditional Graeco-Roman religion to Christianity has gone unexplained. In dialogue with James Rives and Jörg Rüpke, I argue that Christianity made better use than its religious competition of long-term trends in the Roman Empire, such as expanding literacy, the rejection of sacrifice, the movement toward monotheism, and the closing of the distance between gods and their faithful. The growing skepticism within the city elites regarding the credibility of its traditional religion, the decrease in investments in its material side, and the strength of the Christian organizations were additional factors together with contingent events, such as Constantine's victory and his long rule.
\end{abstract}

\section{Keywords}

demise of religions - Graeco-Roman religion - Christianization - regional differentiation - literacy - sacrifice - urban religion - importance of gods "superlativism"

The end of Graeco-Roman religion has exerted an enormous fascination on the world of ancient and modern historians. ${ }^{1}$ From Edward Gibbon (1737-1794) to Rodney Stark, via the great Adolf von Harnack (1851-1930), its replacement by Christianity has often been discussed (Bremmer 2010a; Baslez 2013; Fousek

1 The literature on many of the subjects discussed in this contribution is voluminous. I therefore limit myself in general to the most recent publications. 
et al. 2018; Schliesser 2019). But why did ancient religion disappear, perhaps not wholly and surviving in fragments, but certainly as the politically and intellectually dominant religion? Most contemporary studies ascribe the ascendancy of Christianity to the military victory of Constantine and the subsequent violent destruction of the religious infrastructure of paganism. Rather striking in this connection is the vocabulary used to describe this process. Thus, to limit myself to some recent examples, Bart Ehrman, in addition to frequently using the terms "destroy" and "destruction," states: "Christianity thrived by killing off its opposition" (2018: 126). Larry Hurtado (2016) called his stimulating study of the rise of Christianity Destroyer of the Gods, and Catherine Nixey (2017), in a book much lauded by nonspecialists of Late Antiquity, launched a furious tirade against the Christians and their deliberate campaign of aggression and violence against those who disagreed with them. ${ }^{2}$ This vocabulary is all the more striking as in recent decades several historians have commented upon the passivity of the pagans in the face of Christian destruction (Frankfurter 2000; Salzman 2006; Wiemer 2011, 171-172), or, to put the phenomenon into more positive terms, noted the seemingly quiet atmosphere in which the transition from paganism to Christianity took place (Bowersock 2000, 134-147, 159-172; Brown 2004; Wiemer 2011, 161; Rohmann 2016, 15).

Indeed, a number of recent studies has nuanced not only the idea of religious violence as such (Bremmer 2014; Praet 2014; Mayer 2020), but has also refuted the old idea of destructive Christians, monks in particular, who went about destroying pagan temples and sanctuaries, like Is-followers avant la lettre (Hahn et al. 2008; Lavan and Mulryan 2011; Dijkstra 2015); in fact, the fate of temples in the 4 th and $5^{\text {th }}$ centuries is a complicated issue and not easily reduced to one denominator (Caseau 2004; Nordiguian 2009; Schuddeboom 2017; Sotinel 2018; Stoehr 2018; Underwood 2019, 5, 168-169). Even the idea of Christian intolerance has been subjected to an incisive investigation and shown to be less persuasive for the 4 th century, although more so for the $5^{\text {th }}$ and later centuries (Van Nuffelen 2018). Yet, if the transition into a dominant Christian society was relatively peaceful, the question arises why this was the case. At this point, one will be disappointed when looking at the historians quoted. None of them offers a satisfactory explanation. In itself, this is perhaps not wholly surprising, as the matter is obviously complex and the idea of a "soft" transition has only been argued in the last few decades.

Modern research started with Gibbon, who analyzed the rise of Christianity as the triumph of one religion over another. In that view, Constantine's victory

2 Nixey 2017, reviewed, for example, by DeGroot 2017, Whitmarsh 2017, Hughes 2018. Much better, Rebenich 2019. 
was of course of paramount importance. And indeed, its significance has often been discussed and need not be repeated at this point. However, my interest is not in Constantine but in the preceding period. Recently, James Rives (2019b) has persuasively argued that if we say farewell to the idea of one religion vanquishing the other, we have to concentrate on the nature of religion as such in the period under consideration. In other words, we should ask what changed in the nature of religion before Constantine that made the "soft" transition into Christianity more understandable. In this respect, Rives draws attention to Arthur Darby Nock's classic study Conversion (1933, see Bremmer 2016a). As he notes, Nock had observed that the possibility of conversion implied a shift in the nature of ancient religion. Nock's insight chimes with more recent ideas about the nature of religion, in particular its claimed absence as a category in ancient culture (Nongbri 2013; Barton and Boyarin 2016). Even if that conclusion goes much too far, it remains a fundamental idea that religion as such is an analytical concept that is not without its problems and certainly not an ahistorical category. The corollary of this insight is that, if we want to explain the relatively peaceful transition to Christianity as the dominant religion in the Roman Empire, we have to ask which religious changes, if any, occurred in the centuries immediately preceding this transition in order to facilitate this, surely, remarkable fact.

Consequently, my main question here will be: Which religious features of that period, which I mainly limit to the last two centuries before Constantine, could have contributed to the demise of ancient religion in the manner we just sketched? I answer this by focusing on recent publications of two of the best specialists of religion in the Roman Empire, Jörg Rüpke and James Rives. In rather different ways, these two scholars have recently tried to identify important characteristics of the religious transformations of the aforementioned period. Whereas Rüpke has mostly worked on Rome and Roman religion, Rives has concentrated more on the Greek part of the Roman Empire. In this respect, the two studies complement one another well and enable us to have a more balanced view of an area that, to be sure, was connected by the Mediterranean (Woolf 2003; Auffarth 2016; Leppin 2017b), but that nevertheless remained dominated in the West by its Roman background and in the East by Greek culture. We must remain conscious of the important cultural and religious differences in the Empire, as these would last into and perhaps become even more pronounced in Late Antiquity.

Another reason why I have chosen to focus on these two scholars is that they display different methodological approaches. Rives shows a preference for models with a strong focus on sacrifice (see below), undoubtedly also due to the fact that he is preparing a book-length study of this subject. In earlier 
contributions, though, he has also suggested three other important features of imperial religious change: first, a growing emphasis on the articulation of correct belief, recently reformulated by him as a shift from orthopraxy to orthodoxy; second, the rise of a single totalizing discourse; and, third, an increase in individual choice (Rives 2011, 2019a). These features overlap with his earlier characterization of Christianity as defined by exclusivity, totalization, and homogeneity, although he also observes that these characteristics were partly shared by contemporary Graeco-Roman culture (Rives 2005).

Rüpke, on the other hand, is working within the context of the influential Erfurt project of Lived Ancient Religion (Albrecht et al. 2018; Rüpke 2019), in which individualization and the agency of the individual are central, a project that is now continued with a concentration on urban religion. ${ }^{3}$ Rüpke (2016b) never fails to stress that we should speak of "religion in the making," that is, of religion as a dynamic process. In a way, one would have expected Rüpke, with his stress on the individual, to be less focused on models, but that is not the case. In a recent study (Rüpke 2018), he has identified several features as significant for the religious transformations in the earlier Roman Empire. Basically, these are: first, urbanization with its democratization of religious media, Intellektualisierung and the Ökonomisierung of religion; second, the formation of the Roman Empire with its growth of a collective identity, delocalization and, albeit much less developed, institutional coordination; and, third, individualization through literacy.

Neither scholar, though, pays much attention to the chronology of the identified developments, as if these were all more or less contemporary; nor do they pay much attention to the emergence of Christianity in these centuries, although this is, arguably, the most important religious development of the period, ${ }^{4}$ given that by the time of Constantine, something like ten per cent of the population had probably become Christian. ${ }^{5}$ Last but not least, neither shows much interest in the gods/God. This is perhaps not wholly surprising, as absence of attention to the gods is a striking feature of recent work in the history of religion. ${ }^{6}$ Yet, for a proper understanding of the developments studied here, attention to the role and place of the gods will prove indispensable. In what follows, I will therefore discuss the features identified by Rives and Rüpke, but at the same time also take into consideration the rise of Christianity. I will also

3 For a preliminary synthesis, with extensive bibliography, see Rüpke 2020.

4 Admittedly, it is not easy to incorporate the Christians in a study of the ancient, preConstantinian city, but see Pont 2019.

5 Hopkins 1998, but also note, regarding such statistics, the early skepticism of Harnack 1924: 946. For a review of the 2018 reprint of Harnack in 2 volumes, see Brendel 2019.

6 See the perceptive analysis of Gilhus 2016. 
pay some attention to another successful newcomer, albeit not a religion, the cult of Mithras, which was long seen as Christianity's main competitor, even if wrongly, as it illustrates some of the developments that we are interested in.

I will start by looking at religious developments in general during the formation of the Roman Empire in the last two pre-Constantinian centuries and, subsequently, zoom in on literacy and Intellektualisierung, sacrifice, and the gods/God as key features of the religious transformation in those centuries. By doing so, I hope to contribute to identifying those features that will help us to understand the transition to Christianity without, however, any pretension to completeness or suggesting that this identification constitutes the definitive explanation. The problem is complicated and there are no easy solutions. As said, I will take Rives and Rüpke as my starting points, but I will not necessarily follow their categorizations, but present my argument in the order that seems the most persuasive to me.

Evidently, a detailed study of the religious developments of the second and third centuries CE would require a proper book, but, given the constraints of place and time, I will, in a more or less essayistic manner, offer some considerations that might perhaps help in acquiring a better insight in and approach to the problem set out above.

\section{The Impact of the Roman Empire}

The formation of the Roman Empire was a long-lasting process, which only gradually led to a more homogeneous whole, even though important cultural and religious differences continued to exist or even newly emerged (below). As regards religion, in addition to the emergence of Christianity, particularly important developments in the first two centuries of the Christian era were the export of Roman religion to the Western provinces of the Empire, the transformation of Judaism after the fall of the Temple, the "Mysteryfication" of Greek religion, and the renaissance of oracles in Western Asia Minor, whereas all over the Empire we can observe the appearance of individual religious entrepreneurs. Let us take a brief look at all these developments.

With the conquest and colonization of North Africa, Spain, Gaul, Britain, cis-Rhine Germany, and the cis-Danube Balkans, Rome had to export its religion to vast areas that always had had their own religions. Yet the religious transfers that took place were not identical with the rituals and institutions as practiced in the capital. On the contrary. Important priestly functions, such as the Vestal Virgins and Arval Brethren or the flamen Dialis and flamen Martialis, were absent, just like many minor Roman priesthoods. Outside Rome, only a 
few Roman festivals were sufficiently popular to be promulgated over a longer period of time, such as the Saturnalia, Kalendae, and Lupercalia, of which the last two remained popular in the East even into Byzantine times. ${ }^{7}$ From the strongly reduced number of gods, Jupiter, perhaps not surprisingly, remains the most important god in the West, like Zeus in the East. Silvanus and Hercules are much more important in the West than one would have surmised from the evidence of Rome, but in the areas of later conquests and colonization, indigenous gods remain more visible than in the beginning of the Roman expansion in the West (Van Andringa 2011). In general, then, we find a "leaner" version of Roman religion, in which sacrifice remains the most important ritual. ${ }^{8}$ The reason for this development is probably the close connection of Roman religion with the upper class and the city itself, which must have made its wholesale export outside Rome impossible.

Regarding Judaism, we can observe the momentous impact of the destruction of the Temple in CE 7O. From that moment on, there were no longer pilgrimages to Jerusalem, the priesthoods lost their importance, and animal sacrifice was no longer practiced. Given these constraints, it is remarkable that the Jews developed new institutions and now concentrated much effort on the synagogue and its rituals, even though outside their homeland the rituals are not that easy to recover (Lewis 2018). From the second century onward, we can see the rise of the rabbis, but it seems that their influence gradually became much greater in the East than in the West, where their impact has been plausibly denied. ${ }^{9}$

In the Greek world, especially Asia Minor in the course of the second century, Mysteries became increasingly popular, and cults with Mysteries characteristics, or at least with names of functionaries derived from the famous Mysteries of Eleusis and Samothrace, became more and more prominent. Apparently, city elites appropriated Mysteries and their terminology to enhance their own prestige. Via the Mysteries they also communicated with the emperors, whose worship they incorporated into their rituals. Through these restricted cults, elites gradually separated themselves from the rest of their communities, while still keeping a firm eye on the center of real power, the emperor (Belayche 2013; Ferrary 2014: 1:122-131; Bremmer 2016b; Massa 2016; especially, Eckhardt and Lepke 2018). This development did not take place, though, in mainland Greece, where the venerable Eleusinian Mysteries and older Mysteries on the Peloponnese were too established to be used in the same manner.

7 See Graf 2015: 163-183 (Lupercalia), 219-221 (Kalendae).

8 For these developments, see Ando 2007; Woolf 2009; Bertrand 2010; Rives 2014.

9 See Mendels and Edrei 2010, but also see the review by Bloch 2011. 
This aiming at prestige via religion also appears in the case of oracles. Scholars have long noted a revival of interest in oracles and other divinatory rituals in later 1st- and 2nd-century literature and inscriptions (Graf 2005; Bendlin 2006; Nollé 2007; Oesterheld 2008). Yet it is only recently that scholars have focused on the groups that consulted and advertised these oracles. They often belonged to the higher classes who increasingly questioned the traditional gods, thus showing some lack of belief in the tradition. This is not surprising because in Asia Minor Epicurean philosophy - atheism lite - was rather popular among the Greek elites, and its followers could advertise their ideas in public inscriptions, such as the famous one of Diogenes of Oenoanda. ${ }^{10}$ The advertising of the questions, but also revivals of ancient rituals, shows that the elites used religion for a kompetitiver Selbstdarstellung, ${ }^{11}$ which should not be confused with piety of the community as such. ${ }^{12}$

When we look beyond these regional cases, we can also note another, more Empire-wide development. The ordered world of the Empire made it much easier to travel and thus to promote new ideas, although other factors, such as literacy were also important in this respect. Throughout the Empire, therefore, we can observe the emergence of religious entrepreneurs who founded and/ or managed small religious groups or institutions. These groups often operated outside civic religion, but they did not yet develop into a world religion, ${ }^{13}$ like later Christianity and Islam. Some such religious travelers and entrepreneurs are familiar to us, such as the restless Apostle Paul or Mani, the founder of Manichaeism, who moved between Mesopotamia, India, and Sassanian Persia. However, we know absolutely nothing, for example, about the founder and "missionaries" of the cult of Mithras, which rapidly spread in Italy and the Rhine-Danube area from the end of the first century CE. Virtually the only persons who receive some profile in our sources, except for Paul and Mani, are Peregrinus, a Cynic who temporarily converted to Christianity, and Alexander of Abonuteichos, who founded an oracle cult around the snake god Glykon, but the fact that we only know them from pamphlets by the malicious satirist Lucian should make us somewhat suspicious of his reports. ${ }^{14}$

Yet these Lucianic writings, however fictitious many of their details may be, do illustrate an important transformation of religion in the and century,

\footnotetext{
10 Scholz 2017: 170-173 (popularity); for the inscription see, most recently, Hammerstaedt et al. 2017.

11 Thus, rightly, Zimmerman 2018 (quotation at 210).

12 See Chaniotis 2003, whose conclusions fit those of Zimmerman 2018.

13 The term "world religion" was introduced in 1864 by the Dutch historian of religion C. P. Tiele (1830-1902), see Bremmer 2003: 317-318; Auffarth 2005 .

14 For these entrepreneurs, see Wendt 2016; Gordon 2017; Bremmer 2017.
} 
as they show in the case of Alexander of Abonuteichos that his new cult had to compete with Epicureans and Christians to have its truth claims accepted, whereas Lucian's Peregrinus offers a journey in which the protagonist tries out successive philosophical and religious allegiances; similarly, in Apuleius's Metamorphoses, Lucius moves from witchcraft, via the cult of Cybele and the allegorical myths of Cupid and Psyche, to the mysteries of Isis. As Greg Woolf rightly notes: "It is difficult to imagine any of these texts written in earlier centuries" (2017:34).

Despite the growing integration of the Empire, the Roman government rarely interfered in local cults, except for some well-known cases, such as the suppression of the Druids (Hutton 2007) and the damaging of the financial basis of the Egyptian temples, which contributed to a slow downturn of the main centers of Egyptian religion. This created a void, which Christianity started to fill well before Constantine..$^{15}$ Egypt, then, will play no role in the rest of this contribution. The other exception is the occasional persecution of Christians. ${ }^{16}$ From the famous letter of Pliny to the Emperor Trajan onwards, we know that it was enough for the Christians to sacrifice to the gods or emperor to be able to go free. Clifford Ando (2016a) has well analyzed the reason for the Roman nonintervention by showing that it was Roman policy to urge its subjects that religious practices in the future should continue those of the past. He also observes that the name - indeed, any identification - of the god or gods in whose honor the local rites in question were directed are absent from the available literary and legal Roman texts. Apparently, the Roman elite had no real interest in the religions of others, but just wanted to make sure that the social order was maintained by letting their subject communities continue with their customary practices; on occasion, Roman officials even dedicated altars to local gods (Haensch 2017). In one of the oldest of the so-called martyr Acts, the Passio Scilitanorum of $180 \mathrm{CE}$, the Roman governor accuses the Christians of maligning the Roman rites, not the gods. ${ }^{17}$ As also appears from the persecutions under the emperor Valerian, the Roman authorities were primarily interested in the maintenance of rites, not in the worship of the gods. ${ }^{18}$

This situation would last until the 3 rd century. An important milestone for a changing attitude must have been the Constitutio Antoniniana of 212 which gave the citizenship to all free inhabitants of the Empire. There was now no

15 See Bagnall $1988=2003$ Ch. X; 1993: 261-309; see also Choat and Yuen-Collingridge 2019: 71.

16 For a brief, factual survey, see Kinzig 2019.

17 Passio Scilitanorum 3-5, see Bremmer 2020a.

18 See the detailed analysis by Röder 2019: 139-211. 
longer a legal and political distinction between Roman citizens and noncitizens but only between the higher (honestiores) and lower (humiliores) classes (Pferdehirt and Scholz 2012; Ando 2016b). It is this measure that formed the basis for new developments in the 3rd century when the situation of incidental persecutions changed dramatically in $249 \mathrm{CE}$, because the emperor Decius issued an edict obliging everybody to sacrifice to the gods (most recently, Mentxaka 2014; Claytor 2015; Schubert 2016). The Roman state now used all its power to enforce a certain kind of religious uniformity: no tolerance of diversity, no pluralism here. The motivation of Decius has been much debated, but his coins, which have long been neglected in the discussions, show that Decius did not emphasize piety toward the gods. Evidently, he was more interested in enhancing his subjects' loyalty than intervening in their religions. ${ }^{19}$ As such, Decius's religious policy was also part of the universalizing tendency in all aspects of Roman rule, including art, architecture, and administration, which Ando has called the shift "from imperium to patria" (2000: 275) - a tendency that concurs with Rives's notions of homogeneity and totalizing discourse, which we noted in the introduction. Decius's example was followed by several emperors, most notably Valerian and Diocletian, whose persecutions, more cruel in the East than in the West, left a lasting memory, especially in Egypt. ${ }^{20}$

In addition to these various developments, there was also a unifying newcomer, the so-called imperial cult. ${ }^{21}$ Increasingly, in both East and West, temples for the emperors started to appear or their cult was incorporated into existing ones, although less in the Western provinces than in the East (Scheid 2006). Given the power of the emperor, it is not surprising that the elites started to invest in the imperial cult to the detriment of the traditional cults. When we look at the building of new temples in Asia Minor in the 2nd and 3 rd centuries, for example, it seems that new temples for the emperors were only slightly fewer in number than those for the traditional city gods, but there clearly was an important monetary drain toward the imperial cult (Price 1984: 249-274; Pohl 2002; Schollmeyer 2008: 117-138; Lavan 2011: xv-lxv). Yet this investment started to falter in the later 3 rd century, and Simon Price has noted that after Constantine's takeover of power "the cities of Asia Minor no longer sustained the regular apparatus of even a secularized imperial cult." $\mathrm{He}$

19 Thus, persuasively, Bleckmann 2006; numismatically supported by Manders 2012: $253-267$.

20 See most recently, Bratož 2004; Alexandru 2014 (with many earlier references); Shin 2018; Mitchell 2019. Memory: Clarysse 1995; Hidding 2020.

21 For a first introduction, with extensive bibliography, see McIntyre 2019. 
persuasively ascribes this demise of the cult to the diminution of the role of cities and their local elites, who were its main sponsors (1984: 60; Pont 2017).

Price's observations well fit the behavior of the city elites, which we already commented upon in our discussion of the Mysteries and the oracles. Recently, both Jörg Rüpke (2018: 46-48) and Greg Woolf (2017:34-36) have stressed the role of cities in the transformation of religion in the imperial period. This is undoubtedly an important observation. Cities were the nodal points of ancient communication systems and offered religious entrepreneurs the possibilities of wealthy clients, but also the prestige of heading a larger following. On the other hand, to be successful, as Woolf notes, new cults should not be too outrageous, and this can be well seen also in early Christianity, as Paul (1 Cor. 10:31) already exhorts the Jesus followers not to give offense.

However, this focus on the city as a locus for religious innovation calls for at least two nuances. First, concentrating on the city prevents us from seeing the possibilities in the countryside. In the East, this becomes clear in the case of Christianity, which already in the later end century made deep inroads in rural areas in Asia Minor, Phrygia in particular, where, in many respects, Christianity was not that different from local cults (Ameling 2011), but also in Egypt (above), where the ascetic movement gained strength in rural and less densely populated areas (Robinson 2017; McKechnie 2019). In the West, the cult of Mithras became popular along the Danube and Rhine frontiers in an incredibly fast manner from around $100 \mathrm{CE}$, but often in small towns or settlements near army bases; as with Mystery cults in the East (above), the cult of Mithras also became connected to the imperial cult in the later and century. ${ }^{22}$ Their popularity shows that even new cults display geographical differences in the Empire, as the cult of Mithras was hardly present in the East, just as, initially, Christianity was not popular in the West. Second, cities could also be bulwarks of traditional Graeco-Roman religion: the last pagan intellectuals, such as Hypatia in Alexandria, Libanius in Antioch, the Platonic Academy in Athens, and Symmachus in Rome congregated and communicated in large cities. These offered the upper class the possibilities to maintain a lively paganism in the late 4th century, when it became a more or less uniform religion, albeit less and less in the public space (Leppin 2004; Gassman 2020).

In this section, then, we have observed diverse religious developments in different parts of the Roman Empire: in the West the "export" of a "leaner" Roman religion, and in the East a gradual distancing by the elites from their fellow citizens through the creation of Mysteries or "Mysteryfication" of existing cults,

22 For maps and lists of the spread of Mithraea see, most recently: Clauss 2012: 27-29; Walsh 2018: 101-127, to be read with Gordon 2019. 
and in Egypt the slow decline of traditional Egyptian religion. In both parts of the Empire, however, often anonymous religious entrepreneurs emerged, who spread new, global cults, such as Mithras and Isis, but also a new religion with a Jewish god, Christianity, ${ }^{23}$ which increasingly becomes visible in pagan literature from the second half of the second century onwards (Engberg 2011; Fleming 2017; Riedweg 2019). More than 40 years ago, Jonathan Z. Smith termed these differences in cults "locative" and "utopian," which still remains a useful distinction, even though recent scholarship has nuanced the strong opposition between the two (Woolf 2017: 28-29).

Having mostly looked at differences, let us now turn to unifying factors, starting with literacy, which was an important means for connection, communication, and canonization.

\section{$2 \quad$ Literacy and Intellektualisierung}

In his aforementioned study, Jörg Rüpke (2018: 48-49, 53-55) separates literacy from Intellektualisierung, which he ranks under the heading Urbanisierung, but the former is given a separate paragraph called Individualisierung durch Schrift. However, this categorization is less persuasive, as it is difficult to imagine Intellektualisierung without literacy. Here, I will therefore combine both these aspects.

Greek and Roman religion was not a "book-religion" (Bremmer 2010b; Stroumsa 2016b), an expression coined in 1872 by Friedrich Max Müller (1872: 30, 35). In Greece, the only areas of religious ritual in which books and texts became prominent were divination and initiation. For example, many questions have survived from the Oracles of Delphi, Didyma, and Dodona, and books and texts played an important role in the off-center religious group of the Orphics. ${ }^{24}$ However, the probable use of books during their initiations was highly unusual and, consequently, Demosthenes (18.259) could ridicule his opponent Aeschines by saying: "when you became a man, you used to read for your mother the books as she performed the initiation rites."

Unlike in Greece, in Italy books did play a role in normative religious life: witness the Etruscan librifatales or libri pontificales and the Roman Sibylline Books. In line with the structure of Roman religion, however, there was no free access to these important books, and the senate kept them under lock and key (Guittard 2007; Cancik 2008: 2:88-114; Souza 2010; Belayche 2018). But, as in

23 For these gods, although not the Jewish/Christian one, see Woolf 2018-2019.

24 As is well stressed by Gordon 2012: 145-47; see also several studies in Lardinois et al. 2011. 
Greece, there was a much wider use of writing in Rome than just books that have some resemblance to our sacred books. Indeed, writing was important for the management of Roman cults and sanctuaries, although that is not to say that the Romans used a written liturgy to perform their rituals, such as we know from Christian services. Books like the Sibylline Books were there to help with the exegesis of ritual performance, rather than functioning as archives of theological knowledge - though we have to be careful with such statements, as none of the books have survived (Woolf 2012). Still, both Greeks and Romans never even came close to having a holy book. ${ }^{25}$

What about the function of literacy in the period that interests us here? Let us first note that the growing integration of the Empire promoted overall literacy, as Keith Hopkins stressed in a suggestive article with the catchy title "Conquest by Book" (Hopkins 1991: $158=2018: 390$ ). This did not mean that everybody could read and write but certainly that the elite could. However, literacy was not limited to the absolute top of society, but also reached the local sub-elites. Hopkins even persuasively argued that early Christianity could not have expanded "across the whole empire without significant subelite literacy." 26

It is different with Jörg Rüpke, who concentrates on the connection between literacy and individualization, the latter being one of the successful Erfurt projects (Rüpke 2018: 53-55). ${ }^{27}$ And indeed, this focus compares well with the ideas of Guy Stroumsa $(2005,2016 \mathrm{a})$, regarding literacy as a kind of replacement of sacrifice and leading to interiorization of religion in Late Antiquity. Yet, even though literacy can lead to individualization, it can also lead to the establishment of communities. When we look at the Roman Empire, three communities stand out in their prominent usage of literacy as regards connectivity and canonization: the Jews, the Manichaeans, and the Christians.

The Palestinian rabbis must have communicated with their fellow Jews in Babylonia but also with those in areas closer by, such as Egypt and Syria. Yet these communications seemed to have been limited to the more Eastern parts of the Roman Empire and across its borders to the Sassanian domain (Hezser 2015). The letters of Mani and other Manichaeans were also more prominent in the East than in the West, where Manichaeism was less popular, despite famous adherents like Augustine (Gardner 2013, 2020: 9-11). However,

25 See Macrae 2016: “As Catherine Bell puts it, Scripture is 'text and then some,' a phenomenologically distinct kind of sacred text; (Roman) civil theology never quite became anything other than text" (143).

$26 \quad$ Note also the qualifications by Woolf 2015 .

27 For the Erfurt project, see Fuchs et al. 2020. 
the biggest usage of literacy can be found among the early Christians, among whom letters played an important role from the very beginning, witness Paul's letters to cities in Asia Minor, mainland Greece, and even Rome. In the and century we have well-known letters from the congregation in Rome to Corinth ( 1 Clement), the letters of Ignatius, the letter from Vienne and Lyons to the churches in Asia Minor and Phrygia about their martyrs in 177 CE and the letter by the Church of Smyrna to that in Philomelium about the martyrdom of Polycarp. These surviving letters must be the tip of an iceberg, and the early Christian movement has been plausibly called "a movement of letter writers" (Stowers 1986: 15). ${ }^{28}$ In the case of Bishop Dionysius of Corinth, whose letters had probably been collected like those of Paul, we can even reconstruct his network through the many letters he wrote to Greek congregations, from Athens to Crete and Nicomedia, about chastity, unity, and heresies, such as those of Marcion. ${ }^{29}$ The letters show that Dionysius was the spider in a wide web or network of Christian churches around $170 \mathrm{CE} .{ }^{30}$ Their authority is also attested by the fact that people falsified and reworked them, even during his own lifetime (Eusebius, $H E$ 4.23.12).

But Christians not only wrote letters, they also produced books. This concentration on books may well be part of their Jewish heritage. Since the discovery of the Dead Sea Scrolls we know that the Judaeans actively rewrote and continued to add to their authoritative writings in the Second Temple Period. Their focus on written texts diminished after the destruction of the Temple and the rise of the rabbis, who taught in an oral cultural context (Hezser 2017), but the Christians took over and, perhaps, even intensified this focus on written texts. Larry Hurtado (2016: 118-120) has perceptively observed that we know infinitely more Christian writings from the first three centuries than from any other cultic or religious group but virtually no buildings, whereas from many cults, such as those of Mithras and Isis, we know the buildings, but virtually no discursive texts. ${ }^{31}$

A specialty of this Christian production was the favoring of the codex for its Scriptures. The origin of this preference is still not wholly clear, but after the bloody Judaean revolt of $115^{-117} \mathrm{CE}$ the need to distinguish themselves from the Judaeans/Jews must have been pressing for the early followers of Jesus. That seems to be why they started to use the codex for their authoritative writings

28 More recently, Neil and Allen 2015; an interesting later example: Hieronymus, Ep. 10.3.2. For a possible Jewish background of Paul in this respect, see Doering 2012.

29 For contemporary religious networking, see: Collar 2013; Woolf 2016; Leppin 2019: $235^{-243 .}$

$30 \quad$ See Gamble 1995: 116-118; Concannon 2017.

31 In general, see also Kloppenborg 2014, 2019: 335-339; Hurtado 2016: 105-141. 
instead of the (sc)roll: What could have been safer than the same appearance as Roman legal documents? ${ }^{32}$ In addition, the codex was cheaper, easier to handle, and simpler to carry around. ${ }^{33}$ Its literary layout and composition strongly suggest a still sub-elite readership and audience (Kloppenborg 2014: 59), as we would indeed expect of the early Jesus movement. It is clear, though, that the decision "to go codex," so to speak, must have been taken unanimously by the early Christians, as there is virtually not a single early Christian canonical text found on rolls or scrolls, whereas we do have papyri of paracanonical texts, such as the Shepherd of Hermas or a Gospel Harmony, on rolls. ${ }^{34}$

The "bookish" character of early Christianity came to the fore in various ways. It may suffice here to briefly mention four aspects. First, reading and writing were so important for the early Christians that the early Christian heroes are depicted as literate, Jesus included. ${ }^{35}$ Second, books helped to develop the Christian faith. The emergence of the Christian dogmas and the formulation of the Christian faith, that is, products of the process of Intellektualisierung, are unthinkable without the many writings of the Church Fathers. Third, the rise of the Christian canon was fairly quick, and at the end of the 2nd century the contours of the later canon already become visible, even though its margins remained long debated in many parts of the Christian Church. ${ }^{36}$ Yet, their canonical book, the later Bible, also helped to unite Christians: however "orthodox" or "heretical," they were all Christians who worshiped Christ and read from the Bible. Fourth, literacy can connect but also exclude. From the middle of the 2nd century onwards, Christians started to distinguish between orthodoxy and heresy. This distinction seems to be typical of its time, as it also occurs among Jews and in contemporary philosophy, even though it is applied more forcefully among the Christians. ${ }^{37}$

Naturally, there is much more to say about this topic, but our observations do show that emerging Christianity made more and better use of the expanding literacy than any other contemporary cult or religion. They used it not only for establishing wider communities, but also for drawing boundaries and for

32 For this similarity, see Meyer 2007, which is insufficiently taken into account by Larsen and Letteney 2019.

33 See Wallraff 2013, overlooked by Larsen and Letteney 2019.

34 See, most recently: Bagnall 2009; Hurtado 2018: 43-47; Choat and Yuen-Collingridge 2019: 66-67; Luijendijk 2019.

35 See Kloppenborg 2014: 32-37; add Keith 2011. Kloppenborg 2014: 35-36 wrongly suggests that in Luke 4.16-30 Jesus is depicted as being able to read a book and not a roll, see van Minnen 2001.

36 For an up-to-date, balanced view, see Schröter 2019.

37 Cohen 2010: 534-547; Eshleman 2012: 149-174; Den Dulk 2019 (with extensive bibliography). 
intellectual discussions between themselves and against others. This varied use of literacy gave the early Christians a powerful weapon in their struggles against the Roman government but also an important advantage on the religious marketplace of the time.

\section{$3 \quad$ Sacrifice}

There can be little doubt that animal sacrifice was the most important and significant ritual act of both Greek and Roman religion. ${ }^{38}$ It is not surprising, therefore, that James Rives (2018, 2019a, 2019c) has dedicated a series of articles to the topic, in which he persuasively argues for the importance of sacrifice, and that Guy Stroumsa (2005) has given his book about the religious transformations of Late Antiquity the title of La fin du sacrifice, albeit somewhat misleadingly as nonanimal sacrifice continued being practiced in various ways (Auffarth 2008). As Rives (2019b, 2019c) notes, animal sacrifice was on average more expensive than other sacrifices and thus enabled the wealthy to demonstrate their status and enlarge their prestige. In general, our literary and archaeological sources show that sacrifice was still widely practiced in East and West in the 2nd century by both Greek and Roman elites, which helped to create a common religious language in the Empire. ${ }^{39}$

Within this sacrificial landscape, the emperor increasingly became an important, if not the most important figure, representing both the ideal sacrificer and ideal object to whom to offer sacrifice, although not as important as the gods. Simon Price (1984: 207-233) has persuasively argued that we should differentiate between sacrifices "to" and "on behalf of" the emperor. The distinction has been called into question (Friesen 1993: 146-152; Gradel 2002: 28-29), but the first type were much rarer and iconographical representations of sacrifices to a ruler are virtually absent from Asia Minor. ${ }^{40}$ In the Latin West, sacrifices were more often directed to deceased emperors or to the emperor's genius or numen than to the living emperor. Despite these regional differences, the emperor's central position helped to universalize Roman rule, but at the same time the representations left enough leeway for his subjects to practice and interpret the sacrifices in various ways (Rives 2019c), the more so as they lacked a fixed interpretation for the worshipers (Schörner 2019).

\footnotetext{
38 For a recent survey, see Ullucci 2015.

39 In this section, I freely draw upon Bremmer 2018a, to which I refer for extensive bibliography.

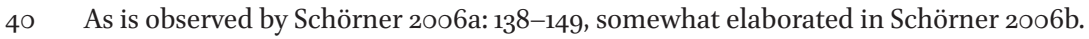


Animal sacrifice started to lose in importance toward the end of the and century. It was not only Christian apologists who criticized animal sacrifices (Rizzi 2001; Bazzana 2009; for later critiques, Burliga 2015), but, for reasons that are not entirely clear, we now also hear of a critique of sacrifice on the pagan side, such as in Lucian's pamphlet On Sacrifice and in the increasingly negative views of Neoplatonist philosophers (Graf 2011; Belayche 2011; Yadin-Israel 2018). In Asia Minor, this intellectual critique coincided with a gradual shift from the offerings of public banquets after sacrifices to building projects by the civic elites (Graf 2015:318-322), thus conforming to the elites' gradual development away from traditional religion, which we already signaled above, but also leading to a diminishment of the place of sacrifice in public life.

For Rome, Latin texts are scarce, but it is noteworthy that, unlike in the Greek novel which teems with sacrifices, there is no mention of sacrifice at all in Apuleius's Latin novel Metamorphoses. If this absence is deliberate, it would fit that from about 200 CE onwards there is a significant decline in Roman sacrificial imagery and in the emphasis on the emperor as sacrificer as well as an increasing focus on nonanimal sacrifice in our visual representations, such as libations and incense (Huet 2008); after $230 \mathrm{CE}$ animal sacrifice has almost disappeared from the imagery in Rome and Italy ${ }^{41}$ We should not confuse representations with practices, but animal sacrifice did indeed start to wane significantly from that period onwards, and quite a few of the larger civic sanctuaries in Gaul and other Western provinces stopped operating after the middle of the 3rd century. Once again, it seems to have been the decreasing interest of the elites in religious euergetism that was responsible for this development, although perhaps more for financial than religious reasons (Van Andringa 2014; Raepsaet-Charlier 2015; Spickermann 2015). Admittedly, we should not assume that this development was the same everywhere. The request by the Umbrian town of Hispellum to Constantine for founding an imperial cult temple to his family, the gens Flavia, in the earlier 330 is an example to the contrary. ${ }^{42}$ Yet this must have been one of the last times that towns would request a temple from the emperor without considering his ideas of sacrifice.

It was not only the critique of animal sacrifice and the shift away from providing sacrificial banquets by the elite that characterized the times. From the middle of the 3 rd century onwards, we also see the emperor appearing less and less on coins as priest, together with a collapse of the cult of the deified emperors (Schumacher 1995). This development went hand in hand with a closer aligning of the emperors with the gods. Unlike in previous centuries,

41 Thus, brilliantly, Elsner 2012; confirmed by Huet 2017.

42 For this much-discussed case, see Lenski 2016: 114-130; McIntyre 2019: 52-56. 
the distance between emperors and divinities now became narrower in imperial propaganda (Stepper 2003: 84-100; Manders 2012: 133-146), but sacrifice apparently was of less importance.

The combination of a gradual intellectual rejection of sacrifice with a diminishing interest in the practice by the elites may well explain Constantine's abhorrence of animal sacrifice, which also seems to have been fed by his Neoplatonist sympathies. ${ }^{43}$ However, if a man of the army like Constantine was negative about blood sacrifice, it would be surprising if that feeling was not much more widespread. ${ }^{44}$ In his case, though, there may have been another factor at play as well. Rives has convincingly argued that animal sacrifice became a much more important factor in Christian thinking after Decius's persecution (Rives 2020), ${ }^{45}$ and this development may also have influenced Constantine's opinion. Still, it is clear that Christian and pagan ideas partially converged at this point, ${ }^{46}$ even if the Christians seem to have rejected sacrifice more strongly, and for different reasons, than their contemporaries. ${ }^{47}$

Let us finally turn to the gods. According to Rüpke, the religious transformations as sketched above happened in individual practices, in the place of religion in society, and in the scope of the religious field as such, but not in the exchange of one god for another. ${ }^{48}$ Is that true? Rüpke's (2016) opus magnum on the history of ancient religions, Pantheon, does not contain a chapter on the gods, and in my review (Bremmer 2018b) I have argued that the Lived Ancient Religion approach neglects the gods by focusing too much on the agency of the individual. That seems to me also to be the case here.

I would like to point to five important developments regarding the gods in the period under discussion. First, in recent decades much attention has been paid to the phenomenon of megatheism, as Angelos Chaniotis has called it.

43 See the balanced discussion of Bleckmann 2012. For the probable influence of Neoplatonism on the Tetrarchic emperors and their environment, see Burgersdijk 2020.

44 Contra Gordon 2019: 467n13, who neglects the epigraphical evidence; see Hotz 2005: 133-144.

45 For the pre-Decius period, see Rebillard 2018.

46 See Eckhardt 2014: "Christian and pagan intellectuals participated at least to some degree in the same discourse on sacrifice" (273).

47 Note also Aurelius Victor 41.12.

48 Rüpke 2018: "dass die dramatischen Veränderungen nicht im Austausch dieses oder jenes Gottes ... im Gunst des Publikums passieren” (28). 
"Great is Artemis of the Ephesians," was shouted for two hours by the craftsmen and other Ephesians in reaction to Paul's preaching, at least according to Acts of the Apostles (19:28). Whatever the historicity of the episode, the acclamation fully fits the 2nd century when we can observe an increasing usage of epithets, expressions, and acclamations that praise and exaggerate the power of individual gods. 49 "Great" (megas), "very great" (megistos), "highest" (hypsistos), "unique god" (heis theos), and "one and only" (heis kai monos) are common expressions in a wide variety of genres, both literary and epigraphically, and occur in cults of many gods. The reason for this development is not wholly clear and probably depends on a variety of factors, such as the increasing autocracy and widening distance between the social classes, the competition between devotees of various divinities, influence from the East where the exaltation of gods was more current than in the West, and, in general in the East, the rise of "superlativism" in society as a whole. ${ }^{50}$ Perhaps not surprisingly, these gods were usually not the traditional ones of the local pantheon, who were closely tied to their own places and whose worship was dominated by the local elite (Chiai 2013, 2016), but new gods like Isis and Sarapis or Theos Hypsistos. The early Christians had joined this chorus, but they did not express it by "superlatives," but by confessing that God is the creator of both heaven and earth, thus stressing his omnipotence..$^{51}$ It is clear that this is not a development toward a Christian-like monotheism, but it does suggest that worshipers invested more affection and emotion (see below) in particular gods instead of in a diverse pantheon. It also fits the trend toward monotheism on a philosophical level in the imperial period, which has been noted by several scholars in recent years (Fürst 2005; Wallraff 2007; Mitchell and Van Nuffelen 2010a, b; Brenk 2012). ${ }^{52}$

A second development, which cannot be separated from the first one, is the rise of the terms Kyrios/Kyria (translated into Latin as dominus/a) and Despotês/ Despoina as divine titles in Egypt, Syria, Anatolia, and Thrace, but hardly in mainland Greece. The title Kyria, "Lady" emerges first in Egypt with Isis in the 2nd century вСЕ and always remained far more popular than Despotês/ Despoina. Its popularity must be due, as Robert Parker suggests, to cultural and linguistic interaction, as comparable titles are well attested in the Levant, not

\footnotetext{
49 For the increase in praise, see Parker 2017: 149-153; Belayche 2020, both with nuanced approaches.

$5^{\circ}$ Chaniotis 2010; note also Belayche 2010; Lanckau 2011; Versnel 2011, 239-307; Parker 2017: 113-153 (with a judicious review of recent scholarship); Chiai 2019.

51 Kelley 2006: 739-743, to be added to Kozlowski 2017. For its background, see Zimmermann 2007: $345-383$.

52 See Macris, Soler, and Van den Kerchove 2o19.
} 
least in the Septuagint. Parker also suggests, not implausibly, that "the nature of the subordination understood to underlie kyrios (and comparable words) may have varied from region to region and even case to case; the other side of the supposed relation (mortal as slave of the god) is seldom made explicit in Greek" (2017: 139-141, with the full evidence and bibliography; here at 141).

However, the last part of his statement is less correct, as Parker clearly neglects the Christian evidence, which speaks a rather different language. The title Kyrios for Jesus/Christ occurs more than 18 o times in the New Testament, in this respect perhaps even trumping Isis. But this title has its counterpart in the qualification "slave of Christ" or "slave of God." The latter goes back to Hebrew 'ebed Yhwh, which the Septuagint translates as doulos theou or doulos Kyriou ("slave of God/Lord": Daniel 1966: 65-92; Floss 1975), and in the New Testament it especially occurs in passages with a background in the Old Testament (Rengstorf 1935: 276-280; Martin 1990: 50-85; Theissen 1992: 187-201).

As regards the former, starting with Paul and later New Testament Letters, ${ }^{53}$ we can find the expression "slave of Jesus/Christ" or "to be the slave of Christ," ${ }^{4}$ all through the 2nd century, as in the Apostolic Fathers (1 Clement 6o.2; Hermas 5.2.1, 6.2.4, 8.10 etc.; 2 Clement 20.1; Ignace, Letter to the Magnesians 2), the apocryphal Acts of the Apostles (Acts of Peter [Latin version] 30, 41), and the Acts of the martyrs (Martyrdom of Polycarp 9.3; Passion of the Scilitans 4). ${ }^{55}$ Already Nock, like Wilhelm Bousset and Adolf Deissmann before him, connected these expressions to the development we have noted above of representing the gods with "superlative" titles. According to Nock, in Christianity the title Kyrios "implies a belief in the divine overruling of the individual, who receives commands from on high" (1972: 1.77), but this view pays insufficient attention to the correlation between the title Kyrios and the self-designation of the faithful as slaves of God/Christ. Being a "slave of Christ" is a sign of total devotion, which in early Christianity is also expressed with the verb latreuô, "to serve." ${ }^{\text {" }}$ As such, as noted by my compatriot Harry Pleket, "these elements acted as a sort of praeparatio evangelica for the common man whose head was not crammed with theological dogma, and facilitated the transition to a structurally subservient religion (Christianity)" (1981:192). It is a sign of the newness of these terms in their religious meaning that Jewish authors who had been

53 Paul: Rom. 1:1, 1 Cor. 7:22, Gal. 1:10, Phil. 1:1. New Testament Letters: Col. 1:7 and 4:2, 2 Tim. 2:24, James 1:1, Jude 1:1, 2 Peter 1:1.

54 Acts 20:19, Rom. 12:11, 14:18 and 16:18, Eph. 6:7, Phil. 2:22.

55 For the later, quite normal, usage, see Sijpesteijn 1994; Haensch 2015.

$5^{6}$ This meaning of "slave of Christ" is well seen by Harris 2001. 
schooled in classical literature, such as Philo and Josephus, avoided as much as possible the term "slave of God" in their voluminous works (Hilhorst 1989: 180).

Third, Parker also notes that we should think less of a subject's relation to a ruler, but "more of that of a social inferior to a superior with whom the inferior may nonetheless be on close terms; while displaying deference, 'mistress' may also establish a claim" (2017: 153). It is clear that Parker thinks of Isis when speaking of "mistress," but the close terms apply even better to early Christianity. In the cases of Rives (2019b) and Rüpke (2018: 28), the former has argued that the difference between Christianity and the rest is related to religions characterized by practices and one characterized by verbal discourse, whereas Rüpke, as we have seen, neglects the gods. Neither of them, though, pays attention to the role of emotions. Although the expanding field of the study of emotions has reached the classical world, until now it has hardly concentrated on early Christianity. ${ }^{57}$ Obviously, this is not the place to analyze this subject in depth. Yet, when we see the attachment of the martyrs to Christ and the emotional descriptions of their interrogations, tortures, and deaths in some of the martyr Acts, it is clear that emotions must have played an important role in early Christianity. In fact, the emergence of "faith" with its Christological focus as a key term of early Christianity relates to the "volcanic eruption" of Jesus devotion, which "emerged consequent upon, and in connection with, the astounding conviction that God had raised Jesus from death and exalted him to heavenly glory." 58 No other cult or religion in the contemporary ancient world knew a comparable devotion with worshipers prepared to die for their faith, except perhaps the Judaeans in their revolts against Rome in the 1st and 2nd centuries.

Fourth, this devotion could also be different from traditional Greek and Roman religion in another manner. Although examples of a lessening of distance between god and worshiper can be found from the start, it seems at first to have been fairly marginal. However, it becomes much more widespread during the imperial period, especially in the new religious movements. In the sanctuaries of Mithras, the worshipers met in a hall close to a relief of the god, which showed his killing of the bull, whereas traditionally the static statue of the god was hidden in the cella of the temple. ${ }^{59}$ In his Metamorphoses (11.24.3), Apuleius depicts the initiation of Lucius into the Mysteries of Isis by having

Most recently: Chaniotis 2013; Caston and Kaster 2016; Sanders and Johncock 2016; Cairns and Nelis 2017; Bremmer 202Oc.

$5^{8}$ Thus, Hurtado 2013b: 35-36. For “faith" see Morgan 2015; Frey 2017; with an enlightening survey of the ancient meaning of the term by Schliesser 2017.

59 Klöckner 2011 highlights this de-traditionalizing aspect. For the relief, see Boschung 202O: $177-187$. 
him stand on a platform close to the statue of the goddess. Once again, it seems that Christianity took this development even further, when we think of the martyr Perpetua, who says that she knew that she could talk to the Lord and was thus able to ask for a vision (Passio Perpetuae 4.1-3). Apparently, the worshipers in these newer cults/religions wanted to be, so to speak, unmittelbar $z u$ Gott. This will have been attractive to their adherents, who belonged to the middle and lower classes, as in traditional Greek and Roman religion priesthoods were always occupied by the elites of the local societies.

Fifth and finally, it is clear that in the East the religious world developed differently to in the West. There are no indications that the traditional Roman upper class also adopted the religious "superlativism." Admittedly, we know very little of the religious convictions of that class, ${ }^{60}$ but, to quote one of the best experts of Roman religion today, John Scheid:

In no case did they regard their gods as absolute masters requiring from mortals a complete and perpetual submission. Roman gods were seen as patroni, as powerful persons who protected and helped their clientes, according to a model of social relations shared by all Romans. The contradiction with the Christian way of seeing things is total.

2016: 139

This means that with the rise of the worship of Christ and other global gods, the traditional Roman view of the gods must have increasingly looked more old-fashioned to many contemporaries. It seems, though, that the traditional Roman religion remained strong in the provinces with a large military population. ${ }^{61}$ Naturally, the latter had close ties with the military establishment and the emperors. Yet, when the latter changed religion, the military followed suit, albeit initially slowly (Tomlin 1998; Haensch 2004).

It is time to draw some conclusions. As I argued in the introduction, the new view of the soft transition into a world dominated by Christianity, asks for an approach that helps us to understand this transition. From that perspective, I would like to note, after a few more general observations, various weaknesses

6o For the few exceptions, see: Rives 1996; Ameling 2010; Scheid 2017.

61 See Alföldy 1989: 349-387 (“Die Krise des Imperium Romanum und die Religion Roms"). 
of traditional religion and some strengths of Christianity in the time before Constantine as explaining factors.

1 For a proper understanding, we first have to ask what we mean when we speak of a world dominated by Christianity. It is obvious that traditional Greek and Roman religion still had a long life ahead of it after Constantine's victory at the Milvian Bridge (Kaegi 1966; Trombley 1985; Harl 199o; many studies in Ameling 2017). As Hartmut Leppin (2012) has persuasively argued, we should not see Christianization as a teleological, unidirectional process, but as a complex of developments, which took place in different rhythms in different places, with some areas embracing Christianity fairly late, such as the western Balkan (Bratož 1996), whereas in other areas that had been converted very early, such as Asia Minor, pagan statuary survived in fully Christianized cities well into the 6th century (Jacobs 2010, 2018, 2020; in general, Smith and Ward-Perkins 2016). In the end, though, as per Leppin, this process gradually led to the hegemony of Christian discourses and practices instead of via a quick, violent transition.

2 One of the most important consequences of Constantine's victory is the fact that by ending the persecutions he enabled the male aristocrats of Roman society, who until that moment had refrained from openly joining the Church, to become Christian, not only without any risk for their lives but even with better chances for their political careers. They would do so, not immediately, but their conversion would accelerate in the later 4th century (Eck 1989; Barnes 1995; Salzman 2002; Cameron 2011: 173-187). This development was aided by the fact that, of all the emperors after Augustus, Constantine had the longest rule, even if over the whole of the Roman Empire only from $324 \mathrm{CE}$. This means that he was far more influential than would have normally been the case, if he had ruled for only, say, five or ten years, as was fairly normal with the emperors before him. His influence was further strengthened through his successors who, with the brief exception of Julian, all kept to the Christian faith.

3 As Leppin notes, the emperor was the most important "Legitimationsressource für Handeln im öffentlichen Raum" (2012: 257). This position enabled him to make changes in the public space. Even though Constantine was careful in doing so, he did take some far-reaching measures. Thus, he made clear that he strongly disapproved of public blood sacrifices, even though his language sometimes is somewhat vague, as in his famous Hispellum rescript (see above), and the precise scope of his antipagan measures remains debated (Bradbury 1994, 1995; Belayche 2001; Delmaire 2004; Wallraff 2011; Ausbüttel 2017). Now, as we have seen, sacrifice was the most central act of ancient religion. How is it possible that Constantine's behavior did not elicit strong protests? The reason must be that, as we have argued above, blood sacrifice had become widely rejected or simply abandoned as a practice by urban elites. By the time 
of Constantine, many temples had collapsed or become neglected (MacMullen 1981: 106), blood sacrifice had lost its previously central role, and even the belief in the divine presence in statues no longer held intellectual credibility, witness Porphyry's allegorizing tractate about them (Miles 2015; Viltanioti 2017; Männlein-Robert 2017; Zingg 2020), ${ }^{62}$ in which he tried to refute the Christian critique (Elliger 1930; Fredouille 1981) ${ }^{63}$ In other words, the whole central complex of pagan material religious culture - sanctuary, sacrifice, and statue - had not become obsolete, but sacrifice no longer enjoyed the undivided support of the highest classes, which until the 3rd century had been its loyal sponsors. Even so, the Christians still used sacrificial terminology when speaking about Christ's crucifixion in the Eucharist (Thomassen 2006: 143-153; Christ 2019), and they also kept or adapted ancient sacrificial rites at the margins of Christendom (Bremmer 2010: 38; Kahlos 2019).

4 The mention of sponsors brings me to another point in which, perhaps, the Lived Ancient Religion approach is less helpful. The focus on individuals is not conducive for seeing power structures and organizational developments. There can be no doubt that the ritual practices of traditional Greek and Roman religion depended on the highest classes. But the new cults, such as those of Mithras and Isis, also depended on financial support. This side of ancient cults does not attract much attention in recent discussions, but it is an important aspect of ancient religion. In this respect, as Gordon convincingly argues, the combined effects of the Antonine (160-195) and "Cyprianic" (249-270) epidemics, the climatic downturn from 150/200 until ca. 300, and the general crisis of the second half of the zrd century,

adversely affected the ability, and slowly also the readiness, of such smalltime religious entrepreneurs to finance their groups, and to persuade others to maintain their payments toward the upkeep of the group. The crucial turning-point was surely the death of an existing leader and the problem of finding a successor(s).

GORDON 2019: 468

In the frontier areas, the moving around of soldiers, who were a sizable part of the worshipers, although certainly not the majority (Gordon 1994, 2009; Latteur 2010), may also have played a role.

The decline of the cult of Mithras in the later zrd century is well documented, but the cult of Isis seems to have lasted longer in certain areas, especially in

62 In general, see: Bergmeier 2016; Klöckner 2019.

63 For the Jewish roots of this critique, see Doering 2020. 
some Roman aristocratic circles into the later 4th century, although elsewhere its evidence also strongly declines in the late 3 rd century and after (Walsh 2018; Sfameni 2012; Bricault 2014). It was different with the Christians, who did not have churches until well into the late 3rd century and even then, not everywhere, nor did they need extensive financial investments in sacrifices. This situation basically changed only with Constantine, who built churches in Rome, the Holy Land, and Constantinople, thus starting the Christianization of the cityscape, a process that eventually would dominate the urban and rural landscape of Late Antiquity (Lenski 2016: 175-96; more general, Brands and Severin 2003; Bauer 2008; Bremmer 2020c).

5 In addition to using his authority against the focal point of traditional religion, Constantine also associated with the bishops, considered himself one of them, and started to give them considerable power and influence. ${ }^{64}$ It should be stressed how unusual this was. Traditional Greek and Roman religion as well as newer cults had many religious functionaries, but in none of them did these functionaries come together, correspond, and form synods or councils. Rüpke explicitly rejects the possibility to look at religion from an organizational point of view. ${ }^{65}$ Yet, in this case, too, Christianity was the exception, and an important one. It is hard to imagine the rise of Christianity without their organization. Literacy must have played an important role here, as bishops corresponded with their colleagues but also with congregations or lay people (Cvetković and Gemeinhardt 2019). In fact, without their organizations it is hard to think of Christianity becoming the power factor that it would develop into during the 4 th and 5 th centuries. The lack of professionalization of the pagan priesthood, of a connecting network, and an empire-wide diversity meant that it was unable to compete with the Christian clergy. ${ }^{66}$

6 Literacyalso must have been an important factor in the Intellektualisierung of traditional religion and the shift from orthopraxy to orthodoxy, as postulated by both Rüpke and Rives. We can notice in the later imperial period a philosophisation of traditional religion, which fits the decreasing interest and investment in ritual practices, but which could not have taken place without the growing impact of literacy in the Empire (Athanassiadi and Macris 2014). Literacy, though, also had another effect. James Rives has stressed the trend to a totalizing discourse and homogeneity. On one level, this is certainly true. This

\footnotetext{
64 For the rise of the bishop, see: Haensch 2007; Girardet 2015: 531-561; Lenski 2016: 76-78; Leppin 2017.

65 Rüpke 2018: “verbietet es sich, 'Religion' als Organisation zu fassen oder primär von ihren - zentralen - Zeichen her zu untersuchen” (12).

66 I have discussed this point more in detail in Bremmer 2011.
} 
is obvious in the religious policies of the emperors before Constantine and is continued by him (Corcoran 2015). Yet, at the same time, we should note an enormous diversity of Christianity from its very beginning, which was maintained by the great dogmatic struggles of the 4 th and 5 th centuries as well as by the support of competing aristocrats. ${ }^{67}$ For contemporaries, Christianity will, perhaps, have looked even more diverse than for us at the great distance of nearly two millennia.

It is time to end. Taking my point of departure from the stimulating studies of Rüpke and Rives, I have tried to identify several factors that contributed to the quiet demise of Greek and Roman religion by stressing the growing skepticism within the elite regarding the credibility of its traditional religion, the decrease in investment in its material side, the emergence of "superlative gods" combined with the trend toward monotheism, the closing of the distance between gods and the faithful, and the strength of the Christian organizations. ${ }^{68}$ Yet even when fitting a long-term trend, contingent events, such as Constantine's victory and his shrewd policies, also played a role. In the end, transformations from one religion to another are not processes that lend themselves to simple explanations. As so often, historical reality remains a hard nut to crack.

\section{Acknowledgments}

This article was started for the 2018-2019 research group "The Demise of Religions," chaired by Michael Stausberg, at the stimulating environment of the Center for Advanced Study, Oslo, and finished in Covid-19 quarantine in Groningen. I am most grateful for information and comments to Raphael Brendel, Laura Feldt, Andreas Merkt, and the anonymous referee.

\section{References}

Albrecht, J., C. Degelmann, V. Gasparini, R. Gordon, M. Patzelt, G. Petridou, R. Raja, A.-K. Rieger, J. Rüpke, B. Sippel, E. Rubens Urciuoli, and L. Weiss. 2018. "Religion in the Making: The Lived Ancient Religion Approach." Religion 48: 568-593.

67 For this diversity, see: Hurtado 2013b; Rebenich 2017 (role of aristocrats); Leppin 2019 even takes this diversity as his point of departure.

68 For other aspects explaining the rise of Christianity, such as charity, the role of women and its exclusivity, see Schliesser 2019, with rich bibliographies. 
Alexandru, I. 2014. "The Great Persecution of Diocletian and its Consequences." In E. Dal Covolo and G. Sfameni Gasparo (eds.), Costantino il Grande alle radici dell'Europa, Vatican City: Libreria Editrice Vaticana, 105-120.

Alföldy, G. 1989. Die Krise des Römischen Reiches. Stuttgart: Steiner.

Ameling, W. 2010. "Pliny: The Piety of a Persecutor." In J. Dijkstra, J. Kroesen, and Y. Kuiper (eds.), Myths, Martyrs, and Modernity, Leiden: Brill, 271-299.

Ameling, W. 2011. "Paränese und Ethik in den kleinasiatischen Beichtinschriften: Zu den Voraussetzungen christlicher Mission in Kleinasien." In R. Deines, J. Herzer, and K.-W. Niebuhr (eds.), Neues Testament und hellenistisch-jüdische Alltagskultur, Tübingen: Mohr Siebeck, 241-249.

Ameling, W. (ed.). 2017. Die Christianisierung Kleinasiens in der Spätantike. Bonn: Habelt.

Ando, C. 200o. Imperial Ideology and Provincial Loyalty in the Roman Empire. Berkeley: University of California Press.

Ando, C. 2007. “Exporting Roman Religion." In J. Rüpke (ed.), Companion to Roman Religion, Oxford: Blackwell, 429-445.

Ando, C. 2016a. “The Rites of Others." In J. Edmondson and A. Keith (eds.), Roman Literary Cultures, Toronto: University of Toronto Press, 254-277.

Ando, C. (ed.). 2016b. Citizenship and Empire in Europe 200-190o: The Antonine Constitution after 1800 Years. Stuttgart: Steiner.

Andringa, W. Van. 2011. "Les dieux, la cité et le pouvoir impérial: Religions et intégration des provinces de l'Occident romain." In G. Moosbauer and R. Wiegels (eds.), Fines imperii - imperium sine fine? Römische Okkupations- und Grenzpolitik im frühen Principat, Rahden: Leidorf, 219-226.

Andringa, W. Van. 2014. "Les dieux changent en Occident (iii ${ }^{\mathrm{e}}-\mathrm{iv}$ e s. apr. J.-C.): Archéologie et mutations religieuses de l'Antiquité tardive." Gallia 71(1): $3^{-10 .}$

Athanassiadi, P., and C. Macris. 2013. "La philosophisation du religieux." In L. Bricault and C. Bonnet (eds.), Panthée, Leiden: Brill, 41-84.

Auffarth, C. 2005. "Weltreligion' als ein Leitbegriff der Religionswissenschaft im Imperialismus." In U. van der Heyden and H. Stoecker (eds.), Mission und Macht im Wandel politischer Orientierungen, Stuttgart: Steiner, 17-36.

Auffarth, C. 2008. “Teure Ideologie - billige Praxis: Die 'kleinen' Opfer in der römischen Kaiserzeit." In E. Stavrianopoulou, A. Michaels, and C. Ambos (eds.), Transformations in Sacrificial Practices: From Antiquity to Modern Times, Münster: LIT, 147-170.

Auffarth, C. 2016. "Das Mittelmeer als handelnde Person der Geschichte: Wie die klimatisch-geographische Lebenswelt Menschen und Religionen prägt." Zeitschrift für Religionswissenschaft 24: 213-220.

Ausbüttel, F. M. 2017. “Constantins Maßnahmen gegen die Heiden." Gymnasium 124: 561-589. 
Bagnall, R. S. 1988. "Combat ou vide: christianisme et paganisme dans l'Égypte romaine tardive." Ktema 13: 285-296.

Bagnall, R. S. 1993. Egypt in Late Antiquity. Princeton, NJ: Princeton University Press.

Bagnall, R. S. 2003. Later Roman Egypt. Aldershot: Ashgate.

Bagnall, R. S. 20o9. Early Christian Books in Egypt. Princeton, NJ: Princeton University Press.

Barnes, T. D. 1995. "Statistics and the Conversion of the Roman Aristocracy." Journal of Roman Studies 85: 135-147.

Barton, C., and D. Boyarin. 2016. Imagine No Religion. New York: Fordham University Press.

Baslez, M.-F. 2013. "La diffusion du christianisme aux $\mathrm{I}^{\mathrm{er}}-\mathrm{II}{ }^{\mathrm{e}}$ siècles: L'église des réseaux." Recherches de Science Religieuse 101, 549-576.

Bauer, F. A. 2008. "Die Stadt als religiöser Raum in der Spätantike." Archiv für Religionsgeschichte 10: 179-206.

Bazzana, G. 2009. "La polemica anti-sacrificale cristiana negli scritti della fine del I e dell'inizio del II secolo." Ricerche Storico-Bibliche 21: 255-270.

Belayche, N. 2001. "Partager la table des dieux: L'empereur Julien et les sacrifices." Revue de l'histoire des religions 218: 457-486.

Belayche, N. 2010. "Deus deum ... summorum maximus (Apuleius): Ritual Expressions of Distinction in the Divine World in the Imperial Period." In S. Mitchell and P. Van Nuffelen (eds.), One God: Pagan Monotheism in the Roman Empire, Cambridge: Cambridge University Press, 141-166.

Belayche, N. 2011. "Entre deux éclats de rire: Sacrifice et représentation du divin dans le De sacrificiis de Lucien." In V. Pirenne-Delforge and F. Prescendi (eds.), "Nourrir les dieux?" Sacrifice et représentation du divin, Liège: Presses universitaires de Liège, $165^{-180 .}$

Belayche, N. 2013. "Lévolution des formes rituelles: hymnes et mystèria." In L. Bricault and C. Bonnet (eds.), Panthée, Leiden: Brill, 17-40.

Belayche, N. 2018. "Content and, or, Context? Subversive Writing in Greek and Roman Religions." In M. Blidstein, S. Ruzer, and D. Stökl Ben Ezra (eds.), Strategies of Religious Subversion: Studies in Discourse with the Work of Guy G. Stroumsa, Tübingen: Mohr Siebeck, 13-29.

Belayche, N. 2020. "L'eulogia dans l'épigraphie religieuse de l'Anatolie impériale." In P. Hoffmann and A. Timotin (eds.), Théories et pratiques de la prière dans l'antiquité tardive (II $-V I^{e}$ s.), Turnhout: Brepols, $17-38$.

Bendlin, A. 2006. "Vom Nutzen und Nachteil der Mantik: Orakel im Medium von Handlung und Literatur in der Zeit der Zweiten Sophistik." In D. Elm von der Osten, J. Rüpke, and K. Waldner (eds.), Texte als Medium und Reflexion von Religion im römischen Reich, Stuttgart: Steiner, 159-207. 
Bergmeier, A. F. 2016. "Vom Kultbild zur Kirche: Veränderte Materialisierungsformen von Heiligkeit in der Spätantike." Distant Worlds Journal 1: 63-79.

Bertrand, A. 2010. "Y a-t-il un paysage religieux colonial? Entre prescription, mimétisme et adaptation: les mécanismes de l'imitatio Romae." Revue de l'histoire des religions 227: 591-6o8.

Bleckmann, B. 20o6. "Zu den Motiven der Christenverfolgung des Decius." In K.-P. Johne, T. Gerhardt, and U. Hartmann (eds.), Deleto paene imperio Romano: Transformationsprozesse des Römischen Reiches im 3. Jahrhundert und ihre Rezeption in der Neuzeit, Stuttgart: Steiner, 57-71.

Bleckmann, B. 2012. "Konstantin und die Kritik des blutigen Opfers." In G. Bonamente, N. Lenski, R. Lizzi Testa (eds.), Costantino prima e dopo Costantino, Bari: Edipuglia, 165-180.

Bloch, R. 2011. Review of Mendels and Edrei, Zweierlei Diaspora: Zur Spaltung der antiken jüdischen Welt. Judaica 67: 118-139.

Boschung, D. 2020. Art and Efficacy. Paderborn: Fink.

Bowersock, G. W. 200o. Selected Papers on Late Antiquity. Bari: Edipuglia.

Bradbury, S. 1994. "Constantine and the Problem of Anti-Pagan Legislation in the Fourth Century." Classical Philology 89: 120-139.

Bradbury, S. 1995. "Julian's Pagan Revival and the Decline of Blood Sacrifice." Phoenix 49: $331-356$.

Brands, G., and H.-G. Severin (eds.). 2003. Die spätantike Stadt und ihre Christianisierung. Wiesbaden: Harrassowitz.

Bratož, R. 1996. "Christianisierung des Nordadria- und Westbalkanraumes im 4. Jahrhundert," in R. Bratož (ed.), Westillyricum und Nordostitalien in der spätrömischen Zeit, Ljubljana: National Museum, 299-366.

Bratož, R. 2004. "Die diokletianische Christenverfolgung in den Donau- und Balkanprovinzen - Verzeichnis der Opfer der Christenverfolgungen in den Donauund Balkanprovinzen." In A. Demandt, A. Goltz, and H. Schlange-Schöningen (eds.), Diokletian und die Tetrarchie, Berlin: de Gruyter, 115-140, 209-252.

Bremmer, J. N. 2003. "Methodologische en terminologische notities bij de opkomst van de godsdienstgeschiedenis in de achttiende en negentiende eeuw." Nederlands Theologisch Tijdschrift 57: 308-321.

Bremmer, J. N. 2010a. The Rise of Christianity through the Eyes of Gibbon, Harnack and Rodney Stark. 2nd ed. Groningen: Barkhuis.

Bremmer, J. N. 2010b. "From Holy Books to Holy Bible: An Itinerary from Ancient Greece to Modern Islam via Second Temple Judaism and Early Christianity." In M. Popović (ed.), Authoritative Scriptures in Ancient Judaism, Leiden: Brill, 327-36o.

Bremmer, J. N. 2011. "Athenian Civic Priests from Classical Times to Late Antiquity: Some Considerations." In M. Horster and A. Klöckner (eds.), Civic Priests: Cult 
Personnel in Athens from the Hellenistic Period to Late Antiquity, Berlin: de Gruyter, 219-235.

Bremmer, J. N. 2014. "Religious Violence between Greeks, Romans, Christians and Jews." In A.-K. Geljon and R. Roukema (eds.), Violence in Early Christianity: Victims and Perpetrators, Leiden: Brill, 8-30.

Bremmer, J. N. 2016a. "Arthur Darby Nock's Conversion (1933): A Balance." In J. Weitbrecht, W. Röcke, and R. Bernuth (eds.), Zwischen Ereignis und Erzählung: Konversion als Medium der Selbstbeschreibung in Mittelalter und Früher Neuzeit, Berlin: de Gruyter, 9-29.

Bremmer, J. N. 2016b. "Imperial Mysteries." Mètis NS 14: 21-34.

Bremmer, J. N. 2017. "Lucian on Peregrinus and Alexander of Abonuteichos: A Sceptical View of Two Religious Entrepreneurs." In R. Gordon, G. Petridou, J. Rüpke (eds.), Beyond Priesthood: Religious Entrepreneurs and Innovators in the Roman Empire, Berlin: de Gruyter, 47-76.

Bremmer, J. N. 2018a "Transformations and Decline of Sacrifice in Imperial Rome and Late Antiquity." In M. Blömer and B. Eckhardt (eds.), Transformationen paganer Religion in der römischen Kaiserzeit, Berlin: de Gruyter, 215-256.

Bremmer, J. N. 2018b. “Jörg Rüpke's Pantheon." Religion in the Roman Empire 4: 107-112.

Bremmer, J. N. 2020a. "Imitation of Christ in the Passion of the Scillitan Martyrs?" In A. Bettenworth and M. Formisano (eds.), For Example: Martyrdom and Imitation in Early Christian Texts and Art, Paderborn: Fink, 143-169.

Bremmer, J. N. 202ob. "Urban Religion, Neighbourhoods and the Early Christian Meeting Places." Religion in the Roman Empire 6: 48-74.

Bremmer, J. N. 2020c. "Epilogue: Final Considerations and Questions Regarding Visual and Textual Emotions." In H. von Ehrenheim and M. Prusac (eds.), Reading Emotions in Ancient Visual Culture, Rome: Swedish Institute, 193-199.

Brendel, R. 2019. Review of Harnack, Die Mission und Ausbreitung des Christentums, 4th ed. Zeitschrift für Geschichtswissenschaft 67: 667-669.

Brenk, F. E. 2012. "Plutarch and 'Pagan Monotheism." In L. Roig Lanzillotta and I. Muños Gallarte (eds.), Plutarch in the Religious and Philosophical Discourse of Late Antiquity, Leiden: Brill, 73-84.

Bricault, L. 2014. "Gens isiaca et identité polythéiste à Rome à la fin du IV e s. apr. J.-C." In L. Bricault and M. J. Versluys (eds.), Power, Politics and the Cults of Isis, Leiden: Brill, 326-359.

Brown, P. 2004. "Conversion and Christianization in Late Antiquity: The Case of Augustine." In C. Straw and R. Lim (eds.), The Past Before Us: The Challenge of Historiographies of Late Antiquity, Turnhout: Brepols, 103-117.

Burgersdijk, D. 2020. "Neoplatonic Philosophy in Tetrarchic and Constantinian Panegyric." In A. Omissi and A. J. Ross (eds.), Imperial Panegyric from Diocletian to Honorius, Liverpool: Liverpool University Press, 167-189. 
Burliga, B. 2015. "Quod gaudium est rivos sanguinis cernere? The Suffering of Animals in the Christian Critique of the Traditional Graeco-Roman Sacrifice." Studia Elblaskie 16: $337-354$.

Cairns, D., and D. P. Nelis (eds.). 2017. Emotions in the Classical World. Stuttgart: Steiner.

Cameron, A. 2011. The Last Pagans of Rome. Oxford: Oxford University Press.

Cancik, H. 2008. Gesammelte Aufsätze. 2 vols. Tübingen: Mohr Siebeck.

Caseau, B. 2004. "The Fate of Rural Temples in Late Antiquity and the Christianisation of the Countryside." In W. Bowden, L. Lavan, and C. Machado (eds.), Recent Research on the Late Antique Countryside, Leiden: Brill, 105-144.

Caston, R., and R. Kaster (eds.). 2016. Hope, Joy, and Affection in the Classical World. New York: Oxford University Press.

Chaniotis, A. 2003. "Negotiating Religion in the Cities of the Eastern Roman Empire." Kernos 16: 177-19o.

Chaniotis, A. 2010. "Megatheism: The Search for the Almighty God and the Competition of Cults." In S. Mitchell and P. Van Nuffelen (eds.), One God: Pagan Monotheism in the Roman Empire, Cambridge: Cambridge University Press, 112-140.

Chaniotis, A. (ed.). 2013. Unveiling Emotions. Stuttgart: Steiner.

Chiai, G. F. 2013. "Die Ortsgebundenheit des Göttlichen bei Macrobius." In A. Fürst, L. Ahmed, C. Gers-Uphaus, and S. Klug (eds.), Monotheistische Denkfiguren in der Spätantike, Tübingen: Mohr Siebeck, 215-242.

Chiai, G. F. 2016. "Symmachus und die Ortsgebundenheit der Götter Roms." Klio 98: 263-294.

Chiai, G. F. 2019. "Due dèi onnipotenti ed i loro fedeli: Osservazioni sui culti di Zeus Alsenos e di Zeus Petarenos nella Frigia di epoca romana." Sileno 45: 39-84.

Choat, M., and R. Yuen-Collingridge. 2019. "Texts without Authors: Unidentified Texts in the Christian Tradition from Roman Oxyrhynchus." Early Christianity 10: 56-71.

Christ, A. 2019. "The Conversion of Sacrifice in Late Antique Art." In D. Olster and C. Raffensperger (eds.), Radical Traditionalism: The Influence of Walter Kaegi in Late Antique, Byzantine, and Medieval Studies, Lanham, MD: Lexington Books, 213-230.

Clarysse, W. 1995. "The Coptic Martyr Cult." In M. Lamberigts and P. van Deun (eds.), Martyrium in Multidisciplinary Perspective: Memorial Louis Reekmans, Leuven: Peeters, 377-395.

Clauss, M. 2012. Mithras: Kult und Mysterium, Darmstadt: von Zabern.

Claytor, W. G. 2015. "A Decian Libellus at Luther College (Iowa)." Tyche 30: 13-18.

Cohen, S. J. D. 2010. The Significance of Yavneh and Other Essays in Jewish Hellenism. Tübingen: Mohr Siebeck.

Collar, A. 2013. Religious Networks in the Roman Empire. Cambridge: Cambridge University Press.

Concannon, C. 2017. Assembling Early Christianity: Trade, Networks, and the Letters of Dionysios of Corinth. Cambridge: Cambridge University Press. 
Corcoran, S. 2015. "From Unholy Madness to Right-Mindedness: Or How to Legislate for Religious Conformity from Decius to Justinian." In N. McLynn, A. Papaconstantinou, and D. L. Schwartz (eds.), Conversion in Late Antiquity: Christianity, Islam, and beyond, Farnham: Ashgate, 67-94.

Cvetković, A., and P. Gemeinhardt (eds.). 2019. Episcopal Networks in Late Antiquity. Berlin: de Gruyter.

Daniel, S. 1966. Recherches sur le vocabulaire de culte dans le Septante. Paris: Klincksieck.

DeGroot, G. 2017. Review of Nixey, The Darkening Age: The Christian Destruction of the Classical World. The Times, 16 September.

Delmaire, R. 2004. "La législation sur les sacrifices au IV e siècle:un essai d'interprétation." Revue historique de droit français et étranger 82: 219-233.

Dijkstra, J. H. F. 2015. "Religious Violence in Late Antique Egypt Reconsidered: The Cases of Alexandria, Panopolis and Philae." Journal of Early Christian History 6: $24-48$.

Doering, L. 2012. Ancient Jewish Letters and the Beginnings of Christian Epistolography, Tübingen: Mohr Siebeck.

Doering, L. 2020. "Bilderverbot und Götzendienst. Zum Verständnis des 'Bilderverbots' in Texten des hellenistisch-frührömischen und des rabbinischen Judentums." In M. Delgado and V. Leppin (eds.), Bilder, Heilige und Reliquien, Stuttgart: Kohlhammer, 21-48.

Dulk, M. Den. 2019. “'One Would Not Consider Them Jews': Reassessing Jewish and Christian 'heresy." Journal of Early Christian Studies 27: 353-381.

Eck, W. 1989. "Religion und Religiosität in der soziopolitischen Führungsschicht der Hohen Kaiserzeit." In W. Eck (ed.), Religion und Gesellschaft in der römischen Kaiserzeit, Cologne: Böhlau, 15-51.

Eckhardt, B. 2014. “'Bloodless Sacrifice': A Note on Greek Vultic Language in the Imperial Era." Greek, Roman, and Byzantine Studies 54: 255-273.

Eckhardt, B., and A. Lepke. 2018. "Mystai und Mysteria im kaiserzeitlichen Westkleinasien." In M. Blömer and B. Eckhardt (eds.), Transformationen paganer Religion in der römischen Kaiserzeit, Berlin: de Gruyter, 39-79.

Ehrman, B. 2018. The Triumph of Christianity. New York: Simon \& Schuster.

Elliger, W. 1930. Die Stellung der alten Christen zu den Bildern in den ersten vier Jahrhunderten. Leipzig: Dieterich.

Elsner, J. 2012. "Sacrifice in Late Roman Art." In C. Faraone and F. Naiden (eds.), Greek and Roman Animal Sacrifice, Cambridge: Cambridge University Press, 120-163.

Engberg, J. 2011. "Martyrdom and Persecution: Pagan Perspectives on the Prosecution and Execution of Christians c.110-210 AD." In J. Engberg, U. H. Eriksen, and A. K. Petersen (eds.), Contextualising Early Christian Martyrdom, Frankfurt: Peter Lang, 93-117. 
Eshleman, K. 2012. The Social World of Intellectuals in the Roman Empire. Cambridge: Cambridge University Press.

Ferrary, J.-L. 2014. Les mémoriaux de délégations du sanctuaire oraculaire de Claros, d'après la documentation conservé dans le Fonds Louis Robert. 2 vols. Paris: de Boccard.

Fleming, R. 2017. "Galen and the Christians: Texts and Authority in the Second Century AD.” In J. Carleton Paget and J. Lieu (eds.), Christianity in the Second Century, Cambridge: Cambridge University Press, 171-187.

Floss, J. P. 1975. Jahweh dienen - Götter dienen. Cologne: Peter Hanstein.

Fousek, J., V. Kaše, A. Mertel, E. Výtvarová, and A. Chalupa. 2018. "Spatial Constraints on the Diffusion of Religious Innovations: The Case of Early Christianity in the Roman Empire." PLoS One 13(12): 1-14.

Frankfurter, D. 2000. “Things Unbefitting Christians': Violence and Christianization in Fifth-Century Panopolis." Journal of Early Christian Studies 8: 273-295.

Fredouille, J.-C. 1981. "Götzendienst." In Reallexikon für Antike und. Christentum 11: 828-895.

Frey, J., B. Schliesser, and N. Ueberschaer (eds.). 2017. Glaube. Tübingen: Mohr Siebeck.

Friesen, S. J. 1993. Twice Neokoros: Ephesus, Asia and the Cult of the Flavian Imperial Family. Leiden: Brill.

Fuchs, M., A. Linkenbach, M. Mulsow, B.-C. Otto, R. B. Parson, and J. Rüpke (eds.). 2020. Religious Individualisations: Historical and Comparative Perspectives. 2 vols. Berlin: de Gruyter.

Fürst, A. 2005. "Christentum im Trend: Monotheistische Tendenzen in der späten Antike." Zeitschrift für Antikes Christentum 9: 807-834.

Gamble, H. 1995. Books and Readers in the Early Church. New Haven, CT: Yale University Press.

Gardner, I. 2013. "Once More on Mani's Epistles and Manichaean Letter-Writing." Zeitschrift für Antikes Christentum 17: 291-314.

Gardner, I. 2020. The Founder of Manichaeism: Rethinking the Life of Mani. Cambridge: Cambridge University Press.

Gassman, M. P. 2020. Worshippers of the Gods: Debating Paganism in the Fourth-Century Roman West. Oxford: Oxford University Press.

Gilhus, I. S. 2016. "What Became of Superhuman Beings? Companions and Field Guides in the Study of Religion." In P. Antes, A. W. Geertz, and M. Rothstein (eds.), Contemporary Views on Comparative Religion. Sheffield: Sheffield University Press, $375-387$.

Girardet, K. M. 2015. Studien zur Alten Geschichte der Europäer. Bonn: Habelt, 531-161. Gordon, R. 1994. "Who Worshipped Mithras?" Journal of Roman Archaeology 7: 459-474. 
Gordon, R. 2009. "The Roman Army and the Cult of Mithras." In Y. Le Bohec and C. Wolff (eds.), L'armée romaine et la religion sous le Haut-Empire romain, Paris: de Boccard, 379-450.

Gordon, R. 2012. "Memory and Authority in the Magical Papyri." In B. Dignas and R. Smith (eds.), Historical \& Religious Memory in the Ancient World, Oxford: Oxford University Press, $145^{-80}$.

Gordon, R., G. Petridou, and J. Rüpke (eds.). 2017. Beyond Priesthood: Religious Entrepreneurs and Innovators in the Roman Empire. Berlin: de Gruyter.

Gordon, R. 2019. Review of Walsh, The Cult of Mithras in Late Antiquity: Development, Decline and Demise ca. A.D. 270-430. ARYS 17: 461-475.

Gradel, I. 2002. Emperor Worship and Roman Religion. Oxford: Oxford University Press.

Graf, F. 2005. "Rolling the Dice for an Answer." In S. I. Johnston and P. T. Struck (eds.), Mantikê, Leiden: Brill, 51-97.

Graf, F. 2011. "A Satirist's Sacrifices: Lucian's On Sacrifices and the Contestation of Religious Traditions." In J. W. Knust and Z. Várhelyi (eds.), Ancient Mediterranean Sacrifice, Oxford: Oxford University Press, 203-213.

Graf, F. 2015. Roman Festivals in the Greek East. Cambridge: Cambridge University Press. Guittard, C. 2007. Carmen et prophéties à Rome. Turnhout: Brepols.

Haensch, R. 2004. "La christianisation de l'armée romaine." In Y. Le Bohec and C. Wolff (eds.), L'armée romaine de Dioclétien à Valentinien I ${ }^{e r}$, Paris: de Boccard, 525-531.

Haensch, R. 2007. "Die Rolle der Bischöfe im 4. Jahrhundert: Neue Anforderungen und neue Antworten." Chiron 37:153-181.

Haensch, R. 2015. "Bescheidenheit ist eine Zier: Der Gebrauch der Demutsformel $\delta \circ \hat{\lambda} \varnothing_{\circ} \theta \varepsilon \circ \hat{v}$ in den Kirchenbauinschriften der spätantiken Patriarchate Antiochia und Jerusalem." In A. B. Kuhn (ed.), Social Status and Prestige in the Graeco-Roman World, Stuttgart: Steiner, 315-339.

Haensch, R. 2017. "Die hohen Vertreter Roms und die lokalen Kulte: Das Beispiel der kleinasiatischen und griechischsprachigen nordafrikanischen Provinzen." In R. Raja (ed.), Contextualising the Sacred in the Hellenistic and Roman Near East, Turnhout: Brepols, 63-72.

Hahn, J., S. Emmel, and U. Gotter (eds.). 2008. From Temple to Church: Destruction and Renewal of Local Cultic Topography in Late Antiquity. Leiden: Brill.

Hammerstaedt, J., P-M. Morel, and R. Güremen (eds.). 2017. Diogenes of Oinoanda: Epicureanism and Philosophical Debates. Leuven: Peeters.

Harl, K. W. 199o. "Sacrifice and Pagan Belief in Fifth- and Sixth-Century Byzantium." Past \& Present 128: 7-27.

Harnack, A. von. 1924. Die Mission und Ausbreitung des Christentums. Leipzig: Hinrichs. Harris, M. J. 2001. Slaves of Christ: A New Testament Metaphor for Total Devotion to Christ. Downers Grove, IL: IVP Academic. 
Hezser, C. 2015. "Crossing Enemy Lines: Network Connections between Palestinian and Babylonian Sages in Late Antiquity." Journal for the Study of Judaism 46: 224-25o.

Hezser, C. 2017. "Bookish Circles? The Use of Written Texts in Rabbinic Oral Culture." Temas Medievales 25: 63-81.

Hidding, A. 2020. The Era of the Martyrs: Remembering the Great Persecution in Late Antique Egypt. Berlin: de Gruyter.

Hilhorst, A. 1989. "'Servir Dieu' dans la terminologie du judaïsme hellénistique et des premières générations chrétiennes de langue grecque." In A. A. R. Bastiaensen, A. Hilhorst, and C. H. Kneepkens (eds.), Fructus Centesimus: Mélanges G. J. M. Bartelink, Steenbrugge: Kluwer, 177-192.

Hopkins, K. 1991. "Conquest by Book." In M. Beard et al. (eds.), Literacy in the Roman World, Ann Arbor: Journal of Roman Archaeology, 133-158.

Hopkins, K. 1998. "Christian Number and Its Implications." Journal of Early Christian Studies 6: $185^{-226 .}$

Hopkins, K. 2018. Sociological Studies in Roman History. Cambridge: Cambridge University Press.

Hotz, S. 2005. "Rituale im öffentlichen Diskurs griechischer Poleis der Kaiserzeit." Ph.D. diss., Heidelberg, Seminar für Alte Geschichte und Epigraphik.

Huet, V. 2008. "L'encens sur les reliefs sacrificiels romains." In L. Bodiou, D. Frère, and V. Mehl (eds.), Parfums et odeurs dans l'Antiquité, Rennes: Presses Universitaires de Rennes, ${ }^{105^{-116 .}}$

Huet, V. 2017. "Roman Sacrificial Reliefs in Rome, Italy and Gaul: Re-constructing Archaeological Evidence?" In C. Moser and J. Knust (eds.), Ritual Matters, Material Residues of Ancient Religion, Ann Arbor: University of Michigan Press, 11-32.

Hughes, B. 2018. Review of Nixey, The Darkening Age: The Christian Destruction of the Classical World. New York Times, 8 June.

Hurtado, L. W. 2013a. "Interactive Diversity: A Proposed Model of Christian Origins." Journal of Theological Studies 64: 445-462.

Hurtado, L. W. 2013b. "Resurrection-Faith and the 'Historical' Jesus." Journal for the Study of the Historical Jesus 11: $35^{-52}$.

Hurtado, L. W. 2016. Destroyer of the Gods: Early Christian Distinctiveness in the Roman World. Waco: Baylor.

Hurtado, L. W. 2018. Texts and Artefacts. London: T\&T Clark.

Hutton, R. 2007. Druids: A History. London: Hambledon Continuum.

Jacobs, I. 2010. "Production to Destruction? Pagan and Mythological Statuary in Asia Minor." American Journal of Archaeology 114: 267-303.

Jacobs, I. 2018. "Pagan-mythological Statuary in Sixth-century Asia Minor." In I. Jacobs and H. Elton (eds.), Asia Minor in the Long Sixth Century: Current Research and Future Directions, Oxford: Oxbow, 29-43. 
Jacobs, I. 2020. “Old Statues, New Meanings: Literary, Epigraphic and Archaeological Evidence for Christian Reidentification of Statuary." Byzantinische Zeitschrift 113: 789-836.

Kaegi, W. E. 1966. "The Fifth-century Twilight of Byzantine Paganism." Classica et Mediaevalia 27: 243-275.

Kahlos, M. 2019. "Shifting Sacrifices: Fifth-century Developments in Ritual Life." In J. W. Drijvers and N. Lenski (eds.), The Fifth Century: Age of Transformation, Bari: Edipuglia, $235^{-245}$.

Keith, C. 2011. Jesus' Literacy: Scribal Culture and the Teacher from Galilee. London: T\&T Clark.

Kelley, N. 20o6. "Philosophy as Training for Death: Reading the Ancient Christian Martyr Acts as Spiritual Exercises." Church History 75: 723-747.

Kinzig, W. 2019. Christenverfolgung in der Antike. Munich: Beck.

Klöckner, A. 2011. "Mithras und das Mahl der Männer: Götterbild, Ritual und sakraler Raum in einem römischen 'Mysterienkult'” In U. Egelhaaf-Gaiser, D. Pausch, and M. Rühl (eds.), Kultur der Antike, Göttingen: Vandenhoeck \& Ruprecht, 200-225.

Klöckner, A. 2019. "Wie wird ein Bild zum Gott? Zur Medialität kaiserzeitlicher Götterbilder." In T. G. Schattner and A. Guerra (eds.), Das Antlitz der Götter - O rosto das divindades, Wiesbaden: Reichert, 79-97.

Kloppenborg, J. S. 2014. "Literate Media in Early Christian Groups: The Creation of a Christian Book Culture." Journal of Early Christian Studies 22: 21-59.

Kloppenborg, J. S. 2019. Christ's Associations: Connecting and Belonging in the Ancient City. New Haven, CT: Yale University Press, 335-339.

Kozlowski, J. M. 2017. "Unum Deum colo quifecit terram et mare et omnia quae in eis sunt: The Formula of Creation and its Functions in the Acts of the Christian Martyrs." Vetera Christianorum 54: 99-110.

Lanckau, J. 2011. "Hypsistos: Cultural Translation of Jewish Monotheism in the Hellenistic Period." Asiatische Studien 65: 861-882.

Lardinois, A., J. Blok, and M. G. M. van der Poel (eds.). 2011. Sacred Words: Orality, Literacy and Religion. Leiden: Brill.

Larsen, M., and M. Letteney. 2019. "Christians and the Codex: Generic Materiality and Early Gospel Traditions." Journal of Early Christian Studies 27: 383-415.

Latteur, O. 2010. "La diffusion du culte de Mithra dans les provinces danubiennes: l'example de la Pannonie Inférieure." Les Études Classiques 78: 187-214.

Lavan, L. 2011. "The End of Temples: Towards a New Narrative?" In L. Lavan and Mulryan, The Archaeology of Late Antique "Paganism," Leiden: Brill, xv-lxv.

Lavan, L., and M. Mulryan (eds.). 2011. The Archaeology of Late Antique "Paganism." Leiden: Brill.

Lenski, N. 2016. Constantine and the Cities. Berlin: de Gruyter, 114-130.

Leppin, H. 2004. "Zum Wandel des spätantiken Heidentums." Millennium-Jahrbuch 1: $59-82$. 
Leppin, H. 2012. "Christianisierungen im Römischen Reich: Überlegungen zum Begriff und zur Phasenbildung." Zeitschrift füt Antikes Christentum 16: 247-278.

Leppin, H. 2017a. "Zu den Anfängen der Bischofsbestellung." In A. Fahrmeir (ed.), Personalentscheidungen für gesellschaftliche Schlüsselpositionen, Berlin: de Gruyter, $33-53$.

Leppin, H. 2017b. "Globalisierung des Altertums in zweierlei Gestalt." Historische Zeitschrift 304: 147-156.

Leppin, H. 2019. Die frühen Christen von den Anfängen bis Konstantin. 2nd ed. Munich: Beck.

Lewis, N. D. 2018. “Did Roman Jews Have Ritual?” Historia religionum 10: 27-39.

Luijendijk, A. 2019. "The Gospel of Mary at Oxyrhynchus (P. Oxy. L 3525 and P. Ryl. III 463): Rethinking the History of Early Christianity through Literary Papyri from Oxyrhynchus." In T. G. Petrey (ed.), Re-Making the World: Christianity and Categories, Tübingen: Mohr Siebeck, 391-418.

MacMullen, R. 1981. Paganism in the Roman Empire. New Haven, CT: Yale University Press.

Macrae, D. 2016. Legible Religion:Books, Gods, and Rituals in Roman Culture. Cambridge, MA: Harvard University Press.

Macris, C., J. Soler, and A. Van den Kerchove (eds.). 2019. "Monotheistic Appropriations of 'Pagan' Figures." Special issue, Revue de l'histoire des religions 236(4).

Manders, E. 2012. Coining Images of Power. Leiden: Brill.

Männlein-Robert, I. 2017. "Zeichen deuten - Zeichen setzen. Porphyrios, die alten

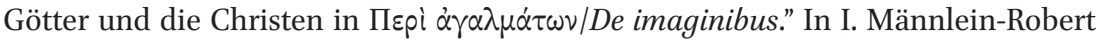
(ed), Die Christen als Bedrohung? Text, Kontext und Wirkung von Porphyrios' Contra Christianos, Stuttgart: Steiner, 177-206.

Martin, D. 199o. Slavery as Salvation. New Haven: Yale University Press.

Massa, F. 2016. "La notion de 'mystères' au iie siècle d.n.è.: regards païens et Christian turn." Mètis NS 14: 109-132.

Mayer, W. 2020. "Religious Violence in Late Antiquity: Current Approaches, Trends and Issues." In J. Dijkstra and C. Raschle (eds.), Religious Violence in the Ancient World, Cambridge: Cambridge University Press, 251-265.

McIntyre, G. 2019. Imperial Cult. Leiden: Brill.

McKechnie, P. 2019. Christianizing Asia Minor. Cambridge: Cambridge University Press.

Mendels, D., and A. Edrei. 2010. Zweierlei Diaspora: Zur Spaltung der antiken jüdischen Welt. Göttingen: Vandenhoeck \& Ruprecht.

Mentxaka, R. 2014. El edicto de Decio y su aplicación en Cartago con base en la correspondencia de Cipriano. Santiago de Compostela: Andavira.

Meyer, E. A. 2007. "Roman Tabulae, Egyptian Christians, and the Adoption of the Codex." Chiron 37: 295-347. 
Miles, G. 2015. "Stones, Wood and Woven Papyrus: Porphyry's On Statues." Journal of Hellenic Studies 135: 78-94.

Minnen, P. van. 2001. "Luke 4:17-20 and the Handling of Ancient Books." Journal of Theological Studies 52: 689-69o.

Mitchell, S. 2019. "Hagiography and the Great Persecution in Sebastea and Armenia Minor." In S. Mitchell and P. Pilhofer (eds.), Early Christianity in Asia Minor and Cyprus, Leiden: Brill, 49-77.

Mitchell, S., and P. Van Nuffelen (eds.). 2010a. One God. Pagan Monotheism. Cambridge: Cambridge University Press.

Mitchell, S., and P. Van Nuffelen (eds.). 201ob. Monotheism Between Christians and Pagans in Late Antiquity. Leuven: Peeters.

Morgan, T. 2015. Roman Faith and Christian Faith: Pistis and Fides in the Early Roman Empire and Early Churches. Oxford: Oxford University Press.

Müller, F. M. 1872. Lectures on the Science of Religion. New York: Scribner, Armstrong, and Co.

Neil, B., and P. Allen (eds.). 2015. Collecting Early Christian Letters: From the Apostle Paul to Late Antiquity. Cambridge: Cambridge University Press.

Nixey, C. 2017. The Darkening Age: The Christian Destruction of the Classical World. London: Mariner Books.

Nock, A. D. 1933. Conversion: The Old and the New in Religion from Alexander the Great to Augustine of Hippo. Oxford: Oxford University Press.

Nock, A. D. 1972. Essays on Religion and the Ancient World. Z. Stewart (ed.). 2 vols. Oxford: Oxford University Press.

Nollé, J. 2007. Kleinasiatische Losorakel. Astragal-und Alphabetchresmologien der hochkaiserzeitlichen Orakelrenaissance. Munich: Beck.

Nongbri, B. 2013. Before Religion. New Haven, CT: Yale University Press.

Nordiguian, L. 2009. "Sur les pas de Renan ... La christianisation des temples païens dans l'arrière-pays de Byblos." Mélanges de l'Université Saint-Joseph 62: 149-19o.

Nuffelen, P. Van. 2018. Penser la tolérance durant l'antiquité tardive. Paris: Cerf.

Oesterheld, C. 2008. Göttliche Botschaften für zweifelnde Menschen: Pragmatik und Orientierungsleistung der Apollon-Orakel von Klaros und Didyma in hellenistischrömischer Zeit. Göttingen: Vandenhoeck \& Ruprecht.

Parker, R. 2017. Greek Gods Abroad. Oakland: University of California Press.

Pferdehirt, B., and M. Scholz (eds.). 2012. Bürgerrecht und Krise: Die Constitutio Antoniniana 212 n.Chr. und ihre innenpolitischen Folgen. Mainz: Schnell \& Steiner.

Pleket, H. W. 1981. "Religious History as the History of Mentality: The 'Believer' as Servant of the Deity in the Greek World." In H. S. Versnel (ed.), Faith, Hope and Worship, Leiden: Brill, 152-192.

Pohl, D. 2002. Kaiserzeitliche Tempel in Kleinasien unter besonderer Berücksichtigung der hellenistischen Vorläufer. Bonn: Habelt. 
Pont, A.-V. 2017. "Dernières mentions des magistratures et des liturgies traditionnelles dans les cités d'Asie mineure: habitus épigraphique et vie institutionnelle locale à la fin du III et au début du IV e siècle." Chiron 47: 35-55.

Pont, A.-V. 2019. "Comment inclure les monothéistes dans une histoire des cités grecques au Haut-Empire? Étude de cas à partir de la Carie.” In N. Andrade, G. Marconi, C. Marcaccini, and D. Violante (eds.), Roman Imperial Cities in the East and in Central-Southern Italy, Rome: L'Erma Di Bretschneider, 141-156.

Praet, D. 2014. "Violence against Christians and Violence by Christians in the First Three Centuries: Direct Violence, Cultural Violence and the Debate about Christian Exclusiveness." In A.-K. Geljon and R. Roukema (eds.), Violence in Early Christianity: Victims and Perpetrators, Leiden: Brill, 31-55.

Price, S. R. 1984. Rituals and Power: The Roman Imperial Cult in Asia Minor. Cambridge: Cambridge University Press.

Raepsaet-Charlier, M.-T. 2015. "Monumentalité, religion publique, vie civique et évergétisme en Gaule romaine." Revue belge de philologie et d'histoire 93: 113-138.

Rebenich, S. 2017. "Kirche in der Spätantike: Koexistenz, Konkurrenz und Konflikt." In P. Gemeinhardt (ed.), Was ist Kirche in der Spätantike?, Leuven: Peeters, 35-56.

Rebenich, S. 2019. Review of Nixey, The Darkening Age: The Christian Destruction of the Classical World (German translation). Süddeutsche Zeitung, 24 July.

Rebillard, É. 2018. "Les autorités romaines et la question de la participation des chrétiens aux sacrifices et fêtes publics aux trois premiers siècles de notre ère." Archives de sciences sociales des religions 182: 17-27.

Rengstorf, K. H. 1935. “doulos etc." In Theologisches Wörterbuch zum Neuen Testament 2, Stuttgart: Kohlhammer, 264-283.

Riedweg, C. 2019. "Stresstest für das globalisierte Imperium Romanum: Zur Ausbreitung des Christentums rund um das Mittelmeer." Gymnasium 126: 449-467.

Rives, J. 1996. "The Piety of a Persecutor." Journal of Early Christian Studies 4: 1-25.

Rives, J. 2005. "Christian Expansion and Christian Ideology." In W. V. Harris (ed.), The Spread of Christianity in the First Four Centuries: Essays in Explanation, Leiden: Brill, $15-41$.

Rives, J. 2011. "Religious Choice and Religious Change in Classical and Late Antiquity: Models and Questions." ARYS 9:265-280.

Rives, J. 2014. "Religion in the Roman Provinces." In C. Bruun and J. Edmondson (eds.), The Oxford Handbook of Roman Epigraphy. Oxford: Oxford University Press, $420-444$.

Rives, J. 2018. "Cult Practice, Social Power, and Religious Identity: The Case of Animal Sacrifice." In S. Alkier and H. Leppin (eds.), Juden - Heiden - Christen? Tübingen: Mohr Siebeck, 71-88.

Rives, J. 2019a. "Animal Sacrifice and Euergetism in the Hellenistic and Roman Polis." Religion in the Roman Empire 5: 83-102. 
Rives, J. 2019b. 'Sacrifice and 'Religion': Modeling Religious Change in the Roman Empire." Religions 10. URL: https://www.mdpi.com/2077-1444/10/1/16 (accessed 8 March 2020).

Rives, J. 2019c. "Roman Empire and Roman Emperor: Animal Sacrifice as an Instrument of Religious Convergence." In B. J. Collins and S. Blakely (eds.), Religious Convergence in the Ancient Mediterranean. Atlanta: Lockwood, 523-540.

Rives, J. 2020. "Animal Sacrifice and the Roman Persecution of Christians (2nd-3rd Centuries CE)." In J. Dijkstra and C. Raschle (eds.), Religious Violence in the Ancient World from Classical Athens to Late Antiquity, Cambridge: Cambridge University Press, $177-202$.

Rizzi, M. 2001. "Il sacrificio pagano nella polemica dell'apologetica christiana del II secolo." Annali di Storia dell'Esegesi 18: 197-209.

Robinson, T. 2017. Who Were the First Christians? Dismantling the Urban Thesis. Oxford: Oxford University Press.

Röder, S. 2019. Kaiserliches Handeln im 3. Jahrhundert als situatives Gestalten. Berlin: de Gruyter.

Rohmann, D. 2016. Christianity, Book-Burning and Censorship in Late Antiquity. Berlin: de Gruyter.

Rüpke, J. 2016a. Pantheon. Munich: Beck.

Rüpke, J. 2016b. "Ancient Lived Religion and the History of Religion in the Roman Empire." Studia Patristica 74: 1-20.

Rüpke, J. 2018. Religiöse Transformationen im römischen Reich. Berlin: de Gruyter.

Rüpke,J. 2019. “Lived Ancient Religions." InJ. Barton (ed.), Oxford Research Encyclopedia of Religion. Oxford: Oxford University Press. URL: https://oxfordre.com/religion/ (accessed 17 January 2020).

Rüpke, J. 2020. Urban Religion: A Historical Approach to Urban Growth and Religious Change. Berlin: de Gruyter.

Salzman, M. 2002. The Making of a Christian Aristocracy. Cambridge, MA: Harvard University Press.

Salzman, M. R. 20o6. “Rethinking Pagan-Christian Violence.” In H. A. Drake (ed.), Violence in Late Antiquity: Perceptions and Practices, Aldershot: Ashgate, 265-286.

Sanders, E., and M. Johncock (eds.). 2016. Emotion and Persuasion in Classical Antiquity. Stuttgart: Steiner.

Scheid, J. 2006. "Paysage religieux et romanisation, quelques réflexions en guise de conclusion." In M. Dondin-Payre and M.-T. Raepsaet-Charlier (eds.), Sanctuaires, pratiques cultuelles et territoires civiques dans l'Occident romain, Brussels: Groeninghe Uitgeverij, 439-448.

Scheid, J. 2016. The Gods, the State, and the Individual: Reflections on Civic Religion in Rome. C. Ando (trans.). Philadelphia: University of Pennsylvania Press. 
Scheid, J. 2017. "Die Träger der paganen Kulte im Imperium Romanum.” In W. Eck and M. Heil (eds.), Prosopographie des Römischen Kaiserreichs, Berlin: de Gruyter, 95-108.

Schliesser, B. 2017. "Faith in Early Christianity: An Encyclopedic and Bibliographical Outline.” In J. Frey, B. Schliesser, and N. Ueberschaer (eds.), Glaube, Tübingen: Mohr Siebeck, 1-50.

Schliesser, B. 2019. "Vom Jordan an den Tiber: Wie die Jesusbewegung in den Städten des Römischen Reichs ankam." Zeitschrift für Theologie und Kirche 116: 1-45.

Schollmeyer, P. 2008. Römische Tempel. Mainz: von Zabern.

Scholz, P. 2017. "Gute und in jeder Hinsicht vortreffliche Männer: Überlegungen zur Funktion und Bedeutung der paideia für die städtischen Führungsschichten im kaiserzeitlichen Kleinasien." In W. Eck and M. Heil (eds.), Prosopographie des Römischen Kaiserreichs, Berlin: de Gruyter, 155-185.

Schörner, G. 2006a. "Opferritual und Opferdarstellung: Ein Testfall für das ZentrumPeripherie- Modell." In L. de Blois, P. Funke, and J. Hahn (eds.), The Impact of Imperial Rome on Religions, Ritual and Religious Life in the Roman Empire, Leiden: Brill, 138-149.

Schörner, G. 2006b. "Opferritual und Opferdarstellung: Zur Strukturierung der Zentrum-Peripherie-Relation in Kleinasien." In H. Cancik, A. Schäfer, and W. Spickermann (eds.), Zentralität und Religion, Tübingen: Mohr Siebeck, 69-94.

Schörner, G. 2019. "Animal Sacrifice in Roman Asia Minor and Its Depictions: A Cognitive Approach." In P. Meineck, W. M. Short, and J. Devereaux (eds.), The Routledge Handbook of Classics and Cognitive Theory, Abingdon: Routledge, 373-382.

Schröter, J. 2019. "Kanon - Eine neutestamentliche Perspektive." In E. Gräb-Schmidt and V. Leppin (eds.), Kanon, Leipzig: Evangelische Verlagsanstalt, 37-65.

Schubert, P. 2016. "On the Form and Content of the Certificates of Pagan Sacrifice." Journal of Roman Studies 106: 172-198.

Schuddeboom, F. L. 2017. "The Conversion of Temples in Rome." Journal of Late Antiquity 10: 166-186.

Schumacher, L. 1995. “Zur 'Apotheose' des Herrschers in der Spätantike.” In G. Crifò (ed.), Il tardo Impero. Aspetti e significati nei suoi riflessi giuridici. Naples: Edizioni Scientifiche Italiane, $105^{-125}$.

Sfameni, C. 2012. "Isis, Cybele and Other Oriental Gods in Rome in Late Antiquity: 'Private' Contexts and the Role of Senatorial Aristocracy." In A. Mastrocinque and C. Giuffré Scibona (eds.), Demeter, Isis, Vesta, and Cybele, Stuttgart: Steiner, $119-138$.

Shin, M. S. 2018. The Great Persecution: A Historical Re-examination. Turnhout: Brepols. Sijpesteijn, P. J. 1994. "Apphus and Pascentius: servi dei tempore." Archiv für Papyrusforschung 40: 69-70. 
Smith, R., and B. Ward-Perkins (eds.). 2016. The Last Statues of Antiquity. Oxford: Oxford University Press.

Sotinel, C. 2018. "La conversion des lieux de culte, métaphore de la conversion des populations." Archives de sciences sociales des religions 182: 29-48.

Souza, M. de. 2010. "L'utilisation de livres dans les rites romains." In Y. Perrin (ed.), Neronia VIII, Bibliothèques, livres et cultures dans l'empire romain de César à Hadrien, Brussels: Éditions Latomus, $165^{-172 .}$

Spickermann, W. 2015. "Das Ende der Weiheinschriftenkultur in den beiden Germanien." In L. Clemens, H. Merten, and C. Schäfer (eds.), Frühchristliche Grabinschriften im Westen des Römischen Reiches, Trier: Kliomedia, 75-85.

Stepper, R. 2003. Augustus et sacerdos: Untersuchungen zum römischen Kaiser als Priester, Stuttgart: Steiner.

Stoehr, G. W. 2018. "The End of Pagan Temples in Roman Palestine." Ph.D. diss., University of Maryland, College Park. URL: https://drum.lib.umd.edu/bitstream/ handle/1903/21227/Stoehr_umd_o117E_19142.pdf?sequence=1\&isAllowed=y (accessed 8 March 2020).

Stowers, S. 1986. Letter Writing in Greco-Roman Antiquity. Philadelphia: Westminster/ John Knox.

Stroumsa, G. 2005. La fin du sacrifice, Paris: Odile Jacob.

Stroumsa, G. 2016a. The Scriptural Universe of Ancient Christianity. Cambridge, MA: Harvard University Press.

Stroumsa, G. 2016b. "Religious Memory, Between Orality and Writing." Memory Studies 9: 332-340.

Theissen, G. 1992. Social Reality and the Early Christians. Minneapolis: Fortress Press.

Thomassen, E. 2006. “The Reception of Greco-Roman Religious and Cultic Terminology in Judaism and Christianity, with Special Reference to Sacrificial Terminology." In D. Brakke, A.-C. Jacobsen, and J. Ulrich (eds.), Beyond Reception: Mutual Influences between Antique Religion, Judaism, and Early Christianity, Frankfurt: Peter Lang, 137-153.

Tomlin, R. S. O. 1998. "Christianity and the Late Roman Army." In S. Lieu and D. Montserrat (eds.), Constantine: History, Historiography and Legend, London: Routledge, 21-51.

Trombley, F. R. 1985. "Paganism in the Greek World at the End of Antiquity: The Case of Rural Anatolia and Greece." Harvard Theological Review 78: 327-352.

Ullucci, D. 2015. "Sacrifice in the Ancient Mediterranean: Recent Current Research." Currents in Biblical Research 13: 388-439.

Underwood, D. 2019. (Re)using Ruins: Public Building in the Cities of the Late Antique West, A.D. 300-6oo. Leiden: Brill.

Versnel, H. S. 2011. Coping with the Gods. Leiden: Brill, 239-307.

Viltanioti, I.-F. 2017. "Cult Statues in Porphyry of Tyre and Macarius Magnes: Porph. Chr. fr. 76 and fr. 77 (von Harnack).” Journal of Late Antiquity 10: 187-220. 
Wallraff, M. 2007. "Tendenzen zum Monotheismus als Kennzeichen der religiösen Kultur der Spätantike." Verkündigung und Forschung 52.2: 65-79.

Wallraff, M. 2011. "Die antipaganen Maßnahmen Konstantins in der Darstellung des Euseb von Kaisareia.” In J. Hahn (ed.), Spätantiker Staat und religiöser Konflikt: Imperiale und lokale Verwaltung und die Gewalt gegen Heiligtümer, Berlin: de Gruyter, 7-18.

Wallraff, M. 2013. Kodex und Kanon. Berlin: de Gruyter.

Walsh, D. 2018. The Cult of Mithras in Late Antiquity: Development, Decline and Demise ca. A.D. 270-430. Leiden: Brill.

Wendt, H. 2015. At the Temple Gates: The Religion of Freelance Experts in the Roman Empire. Oxford: Oxford University Press.

Whitmarsh, T. 2017. Review of Nixey, The Darkening Age: The Christian Destruction of the Classical World. The Guardian, 28 December.

Wiemer, H.-U. 2011. "Für die Tempel? Die Gewalt gegen heidnische Heiligtümer aus der Sicht städtischer Eliten des spätrömischen Ostens.” In J. Hahn (ed.), Spätantiker Staat und religiöser Konflikt, Berlin: de Gruyter, 159-185.

Woolf, G. 2003. “A Sea of Faith?” Mediterranean Historical Review 18: 126-143.

Woolf, G. 2009. "Found in Translation: The Religion of the Roman Diaspora." In O. Hekster, S. Schmidt-Hofner, and C. Witschel (eds.), Ritual Dynamics and Religious Change in the Roman Empire, Leiden: Brill, 239-252.

Woolf, G. 2012. "Reading and Religion in Rome." In J. Rüpke and W. Spickermann (eds.), Reflections on Religious Individuality, Berlin: de Gruyter, 193-208.

Woolf, G. 2015. “Ancient Illiteracy?” Bulletin of the Institute of Classical Studies 58: 31-42.

Woolf, G. 2016. "Only Connect? Network Analysis and Religious Change in the Roman World." Revista Hélade 2.2, 43-58.

Woolf, G. 2017. "Empires, Diasporas and the Emergence of Religions." In J. Carleton Paget and J. Lieu (eds.), Christianity in the Second Century, Cambridge: Cambridge University Press, $25-38$.

Woolf, G. 2018-2019. "Global Deities: Gods on the Move in the Ancient Mediterranean World." Bandue 11: 111-128.

Yadin-Israel, A. 2018. "Contact Without Borrowing Areal Diffusion, Contact-Induced Continuity, and Late Antique Sacrifice." Journal of Ancient Judaism 8: 230-258.

Zimmerman, K. 2018. “'Small Gods?' Transformationen griechischer Religiosität im Spiegel kaiserzeitlicher Orakelpraxis." In M. Blömer and B. Eckhardt (eds.), Transformationen paganer Religion in der römischen Kaiserzeit, Berlin: de Gruyter, 199-214.

Zimmermann, C. 2007. Die Namen des Vaters. Leiden: Brill.

Zingg, E. 2020. "Zum Verhältnis zwischen dem Anonymus Treu (Par. suppl. gr. 6o7A), Iohannes Lydos, De mensibus und Porphyrios, De simulacris. Nebst Neuedition und Übersetzung der fünfzehn im Anonymus Treu enthaltenen Exegesen typischer Statuen." Wiener Studien 133: 119-167. 